Dr. Heba Mohammed Saad

Volume (3) No. (2) 2020

أساليب التفكير ودلالتها التنبؤية بالإبداع الانفعالي لدى طلاب الجامعة

د. هبة محمد إبر اهيم سعد

http://dx.doi.org/10.29009/ijres.3.2.10 
أساليب التفكير ودلالتها التنبؤية بالإبداع الانفعالي لدى طلاب الجامعة

$$
\text { د. هبة محمد إبراهيم سعد }
$$

مدرس علم النفس التربوي، كلية التربية، جامعة دمياط، مصر

hebasaad2007@yahoo.com

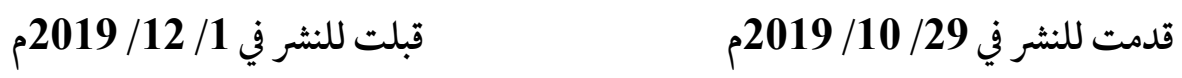

ملخص البحث: هدف البحث إلى الكشف عن إمكانية التنبؤ بالإبداع الانفعالي من خلال أساليب التفكير. وتكونت العينة من (180) طالباً وطالبة جامعياً بالفرقة الرابعة بكلية التربية جامعة دمياط. وتكونت أدوات البحث من مقياس أساليب التفكير، ومقياس الإبداع الانفعالي. وتوصل البحث إلى أن مستوى طلاب الجامعة في أسلوبي التفكير المثالي والتركيبي أعلن من المتوسط. مستوى طلاب الجامعة في الإبداع الانفعالي وأبعاده أعلى من المتوسط. لا توجد فروق ذات دلالة إحصائية في أساليب التفكير تعزى لمتغير التخصص الدراسي (علمي / أدبي). لا توجد فروق ذات دلالة إحصائية في الإبداع الانفعالي وأبعاده (الاستعداد أو التهيؤ الانفعالي - المرونة - الجمدة) تعزى لمتغير التخصص الدراسي (علمي / أدبي)؛ أما في بعد الفعالية تو جد فروق ذات دلالة إحصائية لصالح التخصص الأدبي. لا توجد فروق ذات دلالة إحصائية في أساليب التفكير والإبداع الانفعالي تعزئ لمتغير مكان السكن (ريف / حضر)، توجد علاقة

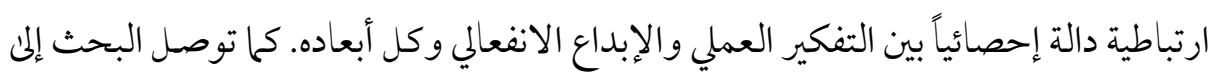
إمكانية التنبؤ بالإبداع الانفعالي لدئ طلاب الجمامعة من خلال التفكير العملي.

$$
\text { الكلمات المفتاحية: التركيبي - المثالي - العملي - التحليلي - الواقعي. }
$$




\title{
Thinking styles and its predictive significance of emotional creativity among university students
}

\author{
Dr. Heba Mohammed Saad, PhD
}

Lecturer of Educational Psychology, College of Education, Damietta University, Egypt.

hebasaad2007@yahoo.com

\section{Received in 29th October 2019}

accepted in 1st December 2019

\begin{abstract}
The research aimed to study the possibility of predicting emotional creativity from thinking styles. The sample consisted of (180) male and female students in the fourth year of the Faculty of Education, Damietta University. The research tools consisted of the measure of thinking styles and the measure of emotional creativity. The research found that the level of university students in both ideal and structural thinking styles is higher than the average. University students level of emotional creativity and its dimensions are above average. There are no statistically significant differences between scientific and literary specializations in thinking styles. There are no statistically significant differences between scientific and literary specializations in dimensions of readiness or emotional readiness, flexibility, novelty, and emotional creativity; while in dimension of effectiveness there are statistically significant differences in favor of literary specialization students. There are no statistically significant differences between rular and urban populations in thinking styles and emotional creativity. There is a statistically significant correlation between practical thinking and emotional creativity and all its dimensions. The research also reached the possibility of predicting the emotional creativity among university students through practical thinking.
\end{abstract}

Keywords: Structural - Ideal - Practical - Analytical - Realistic. 


\section{Summary:}

\section{Introduction:}

As a result of changes and life and academic problems experienced by university students, which are increasing day by day and that makes him in a state of constant emotion, we find that some students have the ability to employ their emotions in an original and flexible in various situations of social interaction, while others lose control of the management of emotions and employ them properly Such as anger, sadness and depression.

In this regard, individuals who have the ability to express genuine, unique and effective emotions that motivate them to think positiveiy in dealing with different situations or to produce some literary, scientific or artistic works are known to be emotional creators (Hosny Al-Najjar, 2017, p. 107).

The concept of emotional creativity consists of four basic components are readiness, flexibility, novelty, and effectiveness. Where the willingness is the tendency of the individual to think and pay attention to his emotions and the emotions of others, to try to understand emotions, and works on emotional growth and works on mental development (Ibrahim Ahmad, 2008, p. 17), And flexibility is the ability to express the state emotional in a positive manner so that the individual can change his responses by changing the situation (Halim al-Ankushi, 2018, p. 511). Novelty is determined when emotion includes an unusual form in the way it is expressed (Karimman, 2002, p. 12), And effectiveness is the ability to the individual to deal with emotions in a way that makes them more control over situations and more interactive than others (Rabia al-Hamdani, 2014, p. 21).

Modern theories have recognized the importance of emotions and their role in stimulating the individual's ability to innovate and problem solving. Emotions that indicate a risk such as sadness, shame, and fear, and may make 
a individual's thinking more analytical and logical, Which reduces his mistakes in problem solving. Sad mood may help to deductive thinking and examination, The positive mood stimulates creativity and problem solving where it enriches the ability to think more flexibly and more simply than limitation, So it is easy to be creativity in expressing feelings and emotions (Bushra Omar and Rabia Zidane, 2014, p. 381; Rasha Eid, 2015, p. 666).

Thinking after one of the finest mental cognitive processes of the individual that distinguishes it from other organisms. It represents the process by which the individual employs his abilities and previous experiences, Processing information, and reveals relationships, in order to solve the problems faced and to decision-making, and adaptation and performance effectively in various situations and environmental variables (Raeda Abu Obeid, 2017, p. 148).

styles of thinking refer to the preferred methods and styles used or used by the individual abilities (Bin Aisha Sumaya, 2014, p. 15), acquire his knowledge, organize ideas and express them in line with the tasks and situations that oppose it (Ola Muhammad, 2014, p.3). The style of thinking used in dealing with social attitudes in life aspects may differ from the style of thinking to solve scientific problems, which means that the individual may use several styles of thinking and these styles change with time (Ahmed Mahmoud, 2014, p. 462).

In this research, we discuss the styles of thinking according to the model Harrison and Bramson, which categorizes them into five basic styles preferred by individuals or deal with the information available when they face problems and situations. This classification is based on the control half of the brain (left and right), each has a different pattern the other in the processing information according to type of performance (logical- non logical) and its content (verbalconceptual). This results in five basic styles of thinking are structural, practical, 
realistic, ideal and analytical, characteristics of each them distinguish (Husni Al-Najjar, 2010, p. 163).

Through the previous presentation, the research questioned the question, since each style of thinking has certain characteristics, which of these styles can be related to emotional creativity and can predict, so the researcher did this research.

\section{Research problem:}

The most noticeable difference in the style individuals think, some of them tend to automatically and retrieve past images, and some of them tend to adhere to all that is agreed upon and applicable, and opposed to any amendment or change, and individuals who tend to renew what is agreed uon and reflected these different thinking styles adopted by ordinary individuals are reflected in their tasks (Salah Pasha, 2005, p. 102).

Therefore, Ola Mohammed (2014, p. 3) emphasizes the importance of studying the styles of thinking in individuals because they represent the most important aspects of human personality, and attention to the thinking style of the individual is the basis for the success of today's generation, which needs to learn the correct intellectual habits to help him to adapt to the development and progress of life.

The style of thinking is a potential force that affects all his interactions and determines his ability to cope different problems and situations.

In spite of this, it was clear to the researcher by looking at the previous studies the following:

1- The scarcity of Arabic studies that dealt with the thinking styles among university students and their relation to emotional creativity. 
2- Contradiction between the results of previous studies that try to detect differences between students of scientific specialization and literary specialization in thinking styles.

3- Contradiction between the results of previous studies that try to detect the differences between students of scientific specialization and literary specialization in emotional creativity.

4- The importance of the research sample, which is the university stage because they are teachers of the future and represent enormous energy and an important human resource for the development and education of a new generation, which necessitates the need to know their styles of thinking and emotional creativity.

In the light of this presentation for the problem of the research and its scientific and logical justification can be formulated in the following questions:

(1) What are the prevailing thinking styles among students of the Faculty of Education?

(2) What is the level of emotional creativity among students of the Faculty of Education?

(3) What kind relationship between the styles of thinking and emotional creativity?

(4) Do the levels of thinking styles of the research sample differ according to the specialization and the place of residence?

(5) Do the components of emotional creativity differ among the research samle depending on the academic specialization, and the place of residence?

(6) You can predict emotional creativity through one of the styles of thinking? 


\section{Objectives of the research}

Current research aims to:

1- Revealing the preferred thinking styles of university students.

2- Revealing the level of emotional creativity among university students.

3- Identify the nature of the relationship between thinking styles and emotional creativity.

4- Revealing the predictability of emotional creativity through a thinking style.

5- Explain the effect of some variables such as specialization, and place of residence in explaining the variation of this phenomenon among students.

\section{Research procedures:}

The researcher followed the following procedures:

1- Reviewing the literature related to the subject of research from a theoretical framework and previous studies and treat it in accordance with the objectives of the research.

2- Preparation of research tools and verification of their psychological characteristics.

3- Determination of the research community are students of the fourth year at the Faculty of Education Damietta University.

4- Selection of the research sample reached (180) student in the fourth year of the Faculty of Education, Damietta University.

5- Apply the thinking styles scale to the research sample.

6- Apply the emotional creativity scale to the research sample.

7- Collection and tabulation of research data and statistically processed using (mean - standard deviations - Pearson correlation coefficient - T test for two independent samples - regression equation) to test research hypotheses.

8- Interpret and discuss research results. 


\section{Research results:}

The study found the following results:

1- Level of university students in both the ideal and structural thinking styles is higher than the average.

2- University students level of emotional creativity and its dimensions are above average.

3- There are no statistically significant differences between scientific and literary specializations in thinking styles.

4- There are no statistically significant differences between scientific and literary specializations in dimensions of readiness or emotional readiness, flexibility, novelty, and emotional creativity; while in dimension of effectiveness there are statistically significant differences in favor of literary specialization students.

5- There are no statistically significant differences between rular and urban populations in thinking styles and emotional creativity.

6- There is a statistically significant correlation between practical thinking and emotional creativity and all its dimensions.

7- The possibility of predicting the emotional creativity among university students through practical thinking. 
مقدمة: - مق

تختلف الحياة من ججتمع إلى آخر نتيجة لاختلاف القيم والعادات و التقاليد والتطورات الحاصـلة للمجتمعات الأخرىن، وأيضـاً مـا يمر به الأفر اد من ظروف الحياة الضــاغطة داخل المجتمع نف سه، وهذا الاختلاف يؤثر بـ شكل مباشر علن سلوك الأفراد وعلى حالتهم النفسية وبالأخص طلاب الجامعة الذين تتفتح أذهانهم وتنضــج أفكارهم في هذه المرحلة، وهم أداة للتطور و التغير، علنى هذا الأســاس يزداد الاهتحام بدر اســة المشـكلات التي تو اجه طلاب الجامعة، والتي تعد من معوقات التقدم والتطور والتنمية، وما يتعرض له طلاب الجامعة في الوقت الحاضر من انخفاض بالاستقرار كان سبباً في زيادة قلقهم إزاء مستقبلهم. ونتيجة للتغيرات والمشـكلات الحياتية والأكاديمية التي يمر بها طلاب الجامعة والتي تزداد يوماً بعد يوم والتي تجعله في حالة انفعال دائم، نجد أن بعض الطلاب لديهم القدرة على توظيف انفعالاتهم بشكل أصيل ومرن في نختلف مو اقف التفاعل الاجتماعي، والبعض الآخر يفقد السيطرة على إدارة انفعالاته وتوظيفها بشكل صحيح مثل الغضب والحزن والاكتئاب. وفي هذا الصدد يُعرف الأفر اد الذين لديهم القدرة على التعبير عن الانفعالات الأصيلة و المتفردة وذات الفعالية والتي تدفعه إلى توجيه التفكير بطريقة إيجابية في التعامل مع المواقف المختلفة أو تدفعه لإنتاج بعض الأعحال الأدبية أو العلمية أو الفنية بأنهم المبدعين انفعالياً (حسني النجار، 2017، ص107). ويتكون مفهوم الإبداع الانفعالي من أربعة مكونات أ سا سية هي الا ستعداد، المرونة، الجلدة، الفعالية، حيث أن الاسـتعداد هو ميل الفرد للتفكير والانتباه لانفعالاته وانفعالات الآخرين، ليحاول فهم الانفعالات، ويعمل على النمو الانفعالي كما يعمل علن النمو العقلي (إبراهيم أحمد، 2008، ص17)، والمرونة هي القدرة علن التعبير عن الحالة الانفعالية بأسلوب إيجابي بحيث يمكن للفرد أن يغير اسـتّجا با ته بتغيير الموقف (حليم العنكوشي، 2018، 
ص511)، والجدة تتحدد حينلما يتضـمن الانفعال شـكلاً غير مألوف في طريقة إظهاره أو

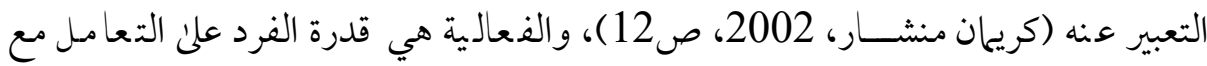
انفعالاته بطريقة تجعله أكثر سـيطرة علن المو اقف وأكثر تفاعلاً من الآخرين (ربيعة الحمداني،

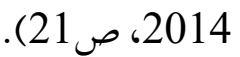

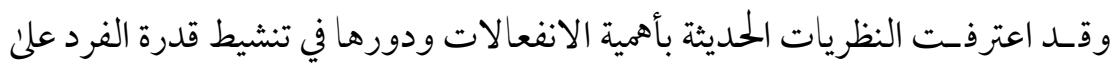

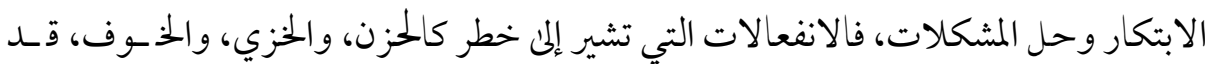
تجعـلـ تفكير الفرد أكثر تحليلية ومنطقية مما يقلل من أخطائه في حل المشكلات، فالمزاج الحزين

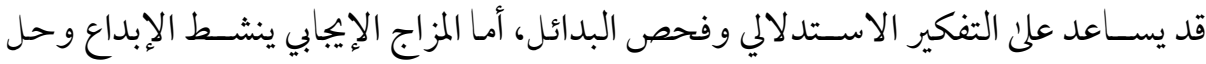

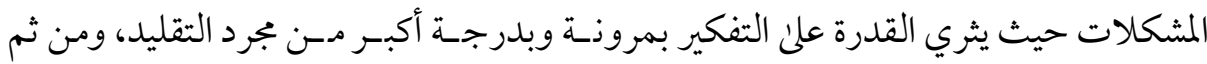

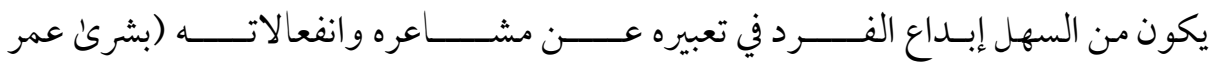

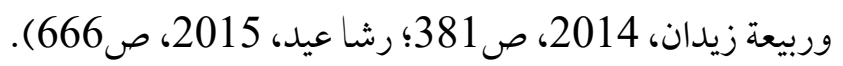
وما سـبق يؤ كد أن الانفعالات تؤثر في قدرة الفردعلن التفكير والتو جه نحو الهدف

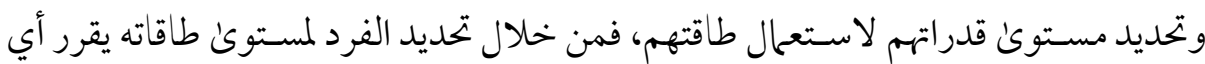

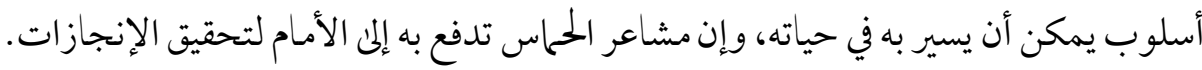

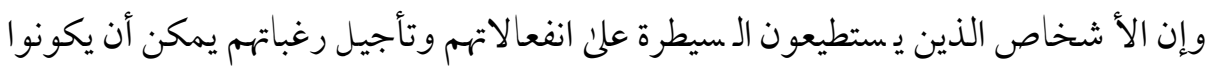

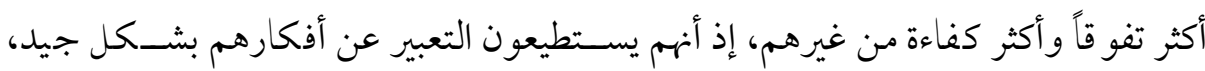

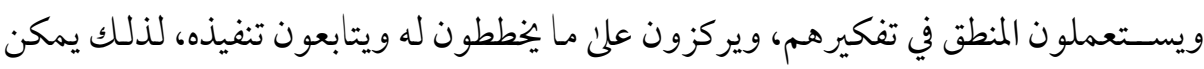

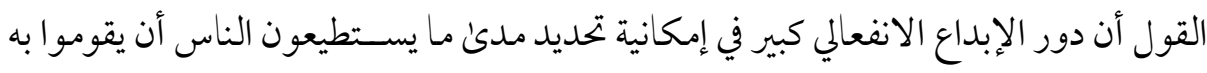

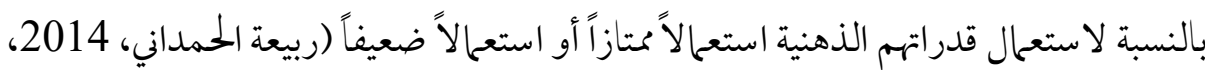
ص20) (20) (n) 
فالإبداع الانفعالي يعتبر الميكانيزم الأســاسي للتحصسيل المعرفي واكتسـاب القدرة على تكوين بنية معرفية كافية للارتقاء بالمهارات المعرفية والتي تدعم القدرة على حل المشـكلات، و التخطيط، واتخاذ القرار، والثـعور برغبة ملحة في التقييم من قبل الآخرين وإصــار أحكام علن الناتج الإبداعي للفرد في المجال المعرفي (عواطف صالح، 2007، ص146). كما أن التفكير يعد من أرقي العمليات العقلية المعرفية للفرد التي تميزه عن غيره من الكائنات الحية الأخرى،، فهو يمثل العملية التي يوظف بها الفرد قدراته وخبراته الســابقة، ويعالج المعلومات، ويكشف العلاقات، وذلك لحل ما يو اجهه من مشكلات واتخاذ القرارات والتكيف والأداء بفعال ية في مختلف المو اقف والمتغيرات البيئية (را ئدة أبو عبيد، 2017، ص 148). (148) (n) وتشير أ ساليب التفكير إلى الطرق والأ ساليب المفضلة التي يستخدمها أو يوظف بها الفرد قدر اته (بن عائشة سمية، 2014، ص 15)، واكتساب معارفه، وتنظيم أفكاره والتعبير عنها بها يتلاءم مع المهام و المو اقف التي تعتر ضه (علا محمد، 2014، ص 3). فأسلوب التفكير المتبع عند التعامل مع المواقف الاجتماعية في الجموانب الحياتية قد يختلف عن أسـلوب التفكير عند حل المسائل العلمية مما يعني أن الفرد قد يستخدم عدة أ ساليب في التفكير وقد تتغير هذه

$$
\text { الأساليب مع الزمن (أحمد محمود، 2014، صـ462). }
$$

ولقد أوضح حاسن الشهري (2006، ص 835) أن هذه الأساليب تختلف من فرد إلى آخر ومن موقف إلى آخر نتيجة لاختلاف نظر الأفراد إلى الأشـياء، وأنشـطة الخلايا العصسبية و عدد ها لدئ الأفراد، وظروف التنشــئة الاجتماءية والتربو ية التي يتعرض لها الفرد، و الاهتما مات التي تتطلب المعالجة الذهنية، والخبرات والأ هداف، و قدرات الأفراد والتي تجعلهم يطورون نتائج فكرية غختلفة. 
وهناك بعض التصـورات النظرية لأسـاليب التفكير والتي تختلف عن بعضـها البعض

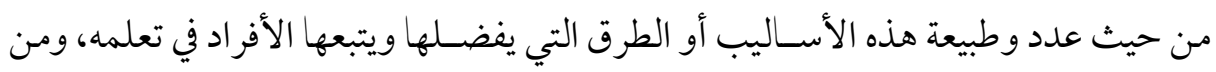

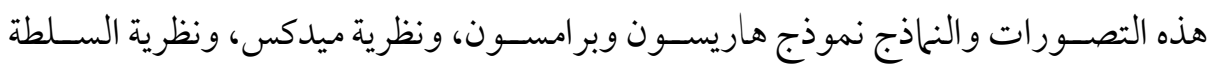

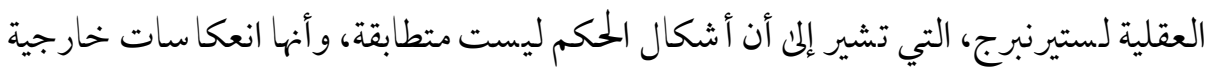

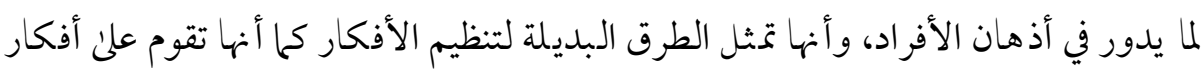

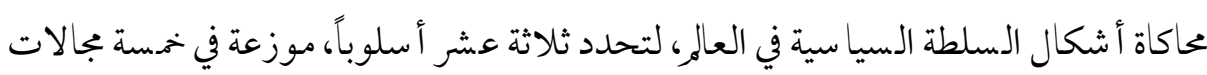

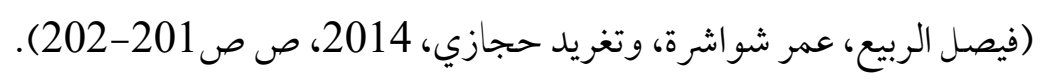

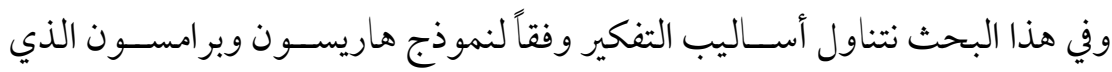

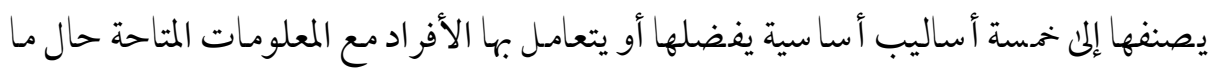

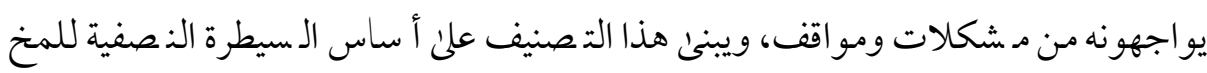
(النمط الأيسر والنمط الأيمن) فلكل منهما نمطاً ختلفاً عن الآخر في معالجة وتجهيز المعلومات التهات

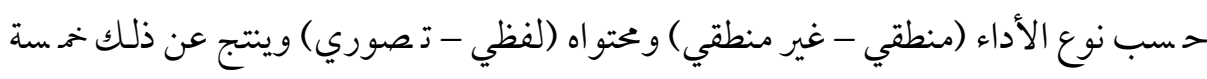

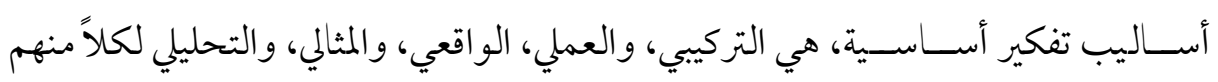
خصائص تميزه (حسني النجار، 2010، صير الن 163).

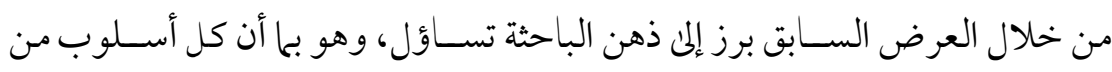

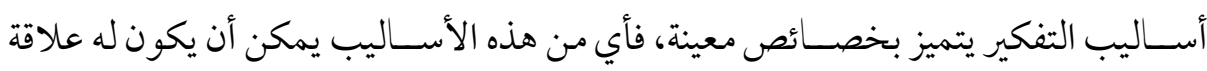

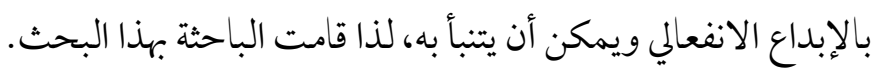




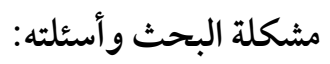

إن أكثر ما يلاحظ اختلاف الأفراد في طريقة تفكيرهم، فمنهم من يميل إلى الناحية

الآلية واسترجاع الصور الماضية، ومنهم من يميل إلى التمسك بكل ما هو متفق عليه ومعمول به، ومعارض أي تعديل أو تغيير، ومن الأفراد من يميل إلى التجديد لما هو قائم ومتفق عليه وتنعكس هذه الأسـاليب المتباينة من التفكير التي يتبناها الأفراد العاديون علن إنجاز المهام

$$
\text { المنوطة بهم (صلاح باشا، 2005، ص102). }
$$

لذا تؤكد علا محمد (2014، ص 3) أهمية دراسـة أسـاليب التفكير لدئ الأفر اد لأنها تمثل أبرز جو انب الشخصية الإنسانية، كما أن الاهتحام بأسلوب التفكير لدئ الفرد هو أساس نجاح جيل اليوم الذي يحتاج إلى تعلم عادات فكرية صسحيحة لتسـاعده علن التوافق مع تطور الحياة وتقدمها. كما أن الطريقة التي يفكر بها الفرد تعد قوة كامنة تؤثر في كافة تفاعلاته، وتحدد قدرته علنى مو اجهة المشكلات و المو اقف المختلفة. وعلن الرغم من ذلك اتضح للباحثة من خلال اطلاعها على الدراسات السابقة ما يلي: 1- ندرة الدرا سات العربية التي تناولت أ ساليب التفكير لدئ طلاب الجامعة وعلاقتها بالإبداع الانفعالي. 2- تناقض بين نتائج الدراسـات السـابقة التي تحاول الكشـفـ عن الفروق بين طلاب التخصص العلمي والتخصص الأدبي في أساليب التفكير. 3- تناقض بين نتائج الدراسـات السـابقة التي تحاول الكشـفـ عن الفروق بين طلاب التخصص العلمي والتخصص الأدبي في الإبداع الانفعالي. 
4- أهمية عينة الدراسـة وهي المرحلة الجامعية لأنهم معلمي ومعلمات المسـتقبل ويمثلن

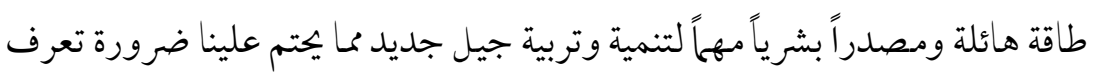
أساليب تفكيرهم و إبداعهم الانفعلي.

وفي ضوء هذا الطرح لمشكلة البحث ومبرراتها العلمية والمنطقية يمكن صياغتها في التساؤلات

$$
\begin{aligned}
& \text { (1) ما أساليب التفكير السائدة لدئ طلبة كلية التربية؟ } \\
& \text { ما مستوئ الإبداع الانفعالي لدئ طلبة كلية التربية؟ } \\
& \text { ما نوع العلاقة بين أساليب التفكير والإبداع الانفعالي؟ }
\end{aligned}
$$

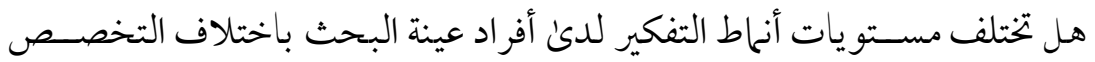

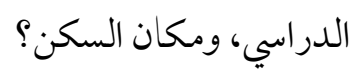

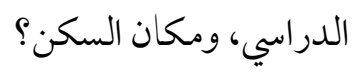

هل يمكن التنبؤ بالإبداع الانفعلي من خلال احدئ أساليب التفكير؟

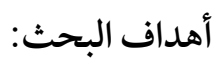

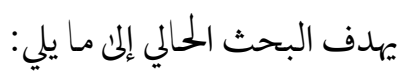

1- الكشف عن أساليب التفكير المفضلة لدئ طلاب الجامعة. 2- الكشف عن مستوئ الإبداع الانفعالي لدئ طلاب الجمامعة. 3- التعرف علن طبيعة العلاقة بين أساليب التفكير والإبداع الانفعلي. 4- الكشف عن إمكانية التنبؤ بالإبداع الانفعالي من خلال احدئ أساليب التفكير. 
5- اسـتجلاء أثر بعض المتغيرات كالتخصـص، ومكان السـكن في تفسـير تفاوت هذه

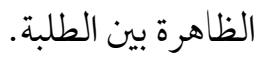

أهمية البحث:

تنطلق أهمية هذا البحث من:

1- إثراء التراث النظري في البيئة العربية حول متغير قلت الدراسـات العربية والبحوث

حوله وهو الإبداع الانفعالي.

2- عرض طبيعة العلاقة والارتباط بين أساليب التفكير والإبداع الانفعالي.

3- أهمية المرحلة التي تتناو هلا الدراســة، وهي المرحلة الجامعية؛ فالشــباب الجامعي هو

أساس المجتمع ومستقبله.

4- الإمداد بمعلومات تســاهم في إعداد البرامـج التدريبية التي تسـتهدف تنمية الإبداع

الانفعالي لدئ طلبة الجامعة.

5- فهم أوسع لأساليب التفكير الأكثر إيبابية في مواجهة أعباء الحياة و التعامـلمعها، كما

أنه من الممكن أن تستخدم نتائج هذه الدراسة في بجال الإرشاد النفسي.

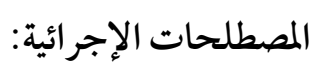

تتمثل مصطلحات ومفاهيم الدراسة الإجرائية فيما يلي:

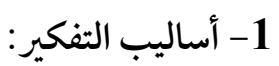

هي الطرق والأ ساليب المفضلة التي يستخدمها طلبة الجلامعة في الحصصول علن المعرفة وتنظيمها واستدعائها في حياتهم الدراسية والعامة (أحمد محمود، 2014، ص 465). 


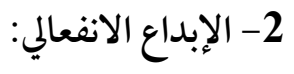

هو قدرة الطالب الجامعي علن الوعي بانفعالاته وانفعالات الآخرين والتعبير عن انفعالاته بشكل يتسم بالأصالة و الفعالية ويُعبر عن قيمه ومعتقداته الخاصة، مما يوجه تفكيره بشـكل إيجابي ويسـاعده علن التعامل مع المو اقف الحياتية، ومشـكلاته الوجدانية والمجتمعية بفاعلية (رشاعيد، 2015، ص 671).

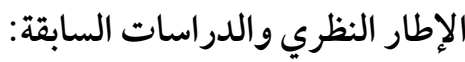

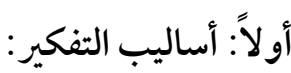

يتفق معظم الباحثين علن أن التفكير هدف مهمم من أهداف التعليم وعلن المؤسـســات التعليمية أن تبذل الو قت والجمهد لملمارسـته، علن ذلك فإن فهم كيف يفكر الناس وكيف يتعاملون بشـكل فعال يشـغل اهتحام كثير من المنظمات التربوية حيث تؤثر تلك العلاقات التي تتم من خلال التفكير الجمعي على الأداء في كافة المنظمات والمؤسـســات كما أن الطريقة التي يفكر بها الفرد تعد قوة كامنة تؤثر في كافة تفاعلاته ومن هنا يتضسح أهمية متغير أسـاليب

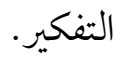

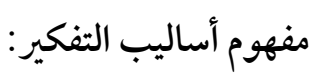
تعددت تعريفات أساليب التفكير ومن أهمها ما يلي: تُعرف صسبحية عحمد (2019، ص 503)؛ غادة محمد وعلية سـيد (2017، ص30)؛ ونافز بقيعي (2012، ص116) أساليب التفكير بأنها طريقة الفرد المفضلة في التفكير عند أداء الأعمال هو ليس قدرة، إنما هو تفضيل لا ستخدام القدرات ويقع بين (الشخصية - أ ساليب

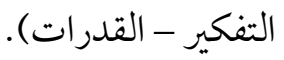


ومصلح المجالي (2019، ص85) يُعرفها بأنها الطريقة المفضلة التي يستخدم بها الفرد

قدراته في التفكير عند قيامه بأداء الأعحال والمههات؛ فهي ليسـت القدرة، ولكنها تفضــيل لاستخدام أي من هذه القدرات في طريقة الأداء.

كذلك تُعرفها غادة محمد وعلية سـيد (2017، ص 30) بأنها عملية عقلية معرفية تؤثر بشـكل مباشر في طريقة وكيفية تجهيز ومعالجة المعلومات والتمثيلات العقلية المعرفية داخل العقل الإنساني.

ويُعرفها أ حمد محمود (2014، ص 465) بأ نها الطرق والأســاليب المفضـلة التي

يستخدمها الطلبة في الحصول علن المعرفة وتنظيمها واستدعائها في حياتهم الدراسية والعامة.

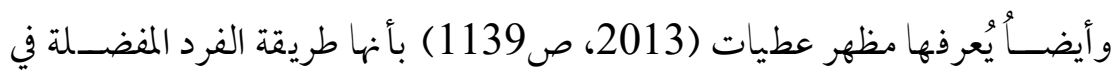
التفكير، التي تؤثر في آلية مدعا لجمة المعلو مات والتمثيلات المعرفية عند أداء الأعمال، ونمط التفكير ليس قدرة، إنها هو تفضيل لاستخدام القدرات ويقع بين الشخصية والقدرات. بينما يُعرفها حسـني النجار (2010، صـو178)، وحاسـن الشـهري (2006، 840) وسـمية بن عائشــة (2015، صـ 15) بأنها بجموعة من الطرق المفضـلة التي يسـتخدمها أو يوظف بها الفرد قدر اته أو ذكاءه وهي الطرق أو المفاتيح لفهم أداء الطلاب، فهي الحد المشترك بين الشخصية والذكاء.

وقام محمد عبد المعطي (2007، ص58) بتعريفها بأنها الطريقة المفضـلة التي يوظف

$$
\text { هها الفرد قدرته أو ذكاءه في مواقف عمله بالتدريس. }
$$

أماصــلاح باشــا (2005، ص108) عرفها بأنها بجموعة الطرق والاسـتراتيجيات الفكرية التي اعتاد الفرد علن أن يتعامـل بها مع ما يو اجهه مـن مشكلات ومو اقف. من خلال التعريفات السابقة يتضح ما يلي: 
اتفاق معظم التعريفات ومنهم تعريفات (صسبحية عممد، 2019، ص503؛ مصـلح المجلي، 2019، ص55؛ غادة محمد وعلية السـيد، 2017، صرئ3 أحمد محمود، 2014، ص465؛ مظهر عطيات، 2013، ص1139؛ نافز بقيعي، 2012، ص116؛ محمد عبد

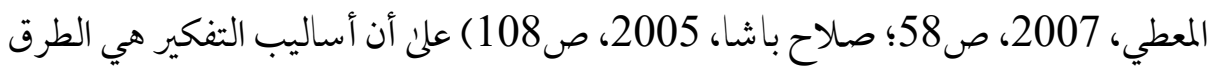

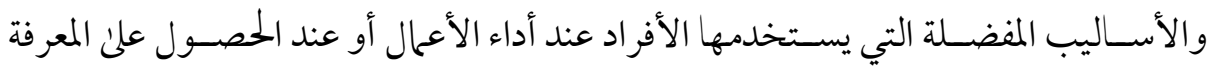
وتنظيمها واستدعائها في حياتهم الدراسية والعامة، وهذه الطرق والأساليب ليست قدرة، إنـا هي تفضيل لاستخدام القدرات ويقع بين الشخصية والقدرات (الشخصية - أساليب التفكير

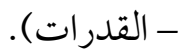

ويضـيف حسـني النجار (2010، ص178)، وحاسـن الشـهري (2006، 840) وسـمية بن عائشـة (2015، ص15) إلى ما سـبق أن أسـاليب التفكير هي مجموعة من الطرق المفضلة التي يستخدمها أو يوظف بها الفرد قدر اته أو ذكاءه وهي الطرق أو المفاتيح لفهم أداء الطلاب، فهي الحد المشترك بين الشخصية والذكاء.

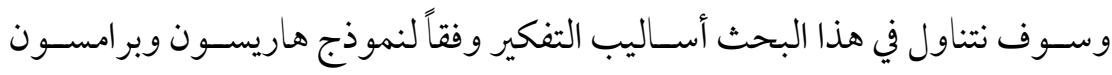
وسوف اتناوها بالتوضيح فيما يلي: أساليب التفكير طبقاً لنظرية هاريسون وبر امسون:

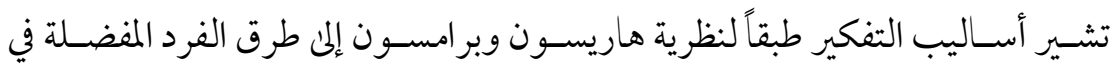

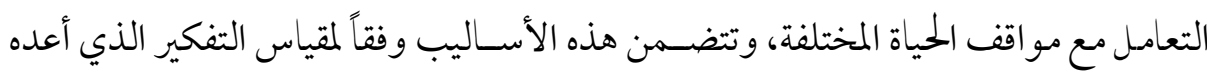

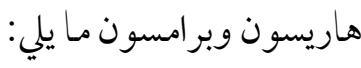




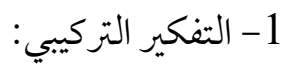

ويقصسد به قدرة الفرد علن التو اصسل لبناء أفكار جديدة وأصسلية مختلفة تماماً عما يفعله الآخرون في القدرة على تركيب الأفكار المختلفة والتطلع إلى بعض وجهات النظر، والربط بين وجهات النظر التي تبدو متعارضة (طلال الزعبي ومحمد الشريدة، 2007، ص33).

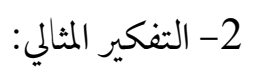

هو قدرة الفرد على تكوين وجهات نظر خختلفة تجاه الأشياء والميل إلى التو جيه المستقبلي و التفكير في الأهداف والاهتحام باحتياجات الفرد وما هو مفيد بالنسـبة له وتركيز الاهتمام على ما هو مفيد للناس والمجتمع ومحور الاهتمام هو القيم (عبود راضي، 2016، ص540). 3- 3 - التفكير العملي:

هو قدرة الفرد على التحقق مما هو صحيح أو خاطئ بالنسبة للخبرة الشخصية المباشرة وحرية التجريب والتفوق في إيجاد طرائق جديدة لعمل الأشياء بالاستعانة بالمو اد الخام المتاحة، وتناول المشكلات بشكل تدريجي، والاهتحام بالعمل والجوانب الإجرائية، والبحث عن الحل

$$
\begin{aligned}
& \text { السريع (محمد كادي، 2016، ص30). } \\
& \text { 4- التفكير التحليلي: }
\end{aligned}
$$

وهو قدرة الفرد علن مو اجهة المشكلات بحرص وبطريقة منهجية والاهتحام بالتفاصيل والتخطيط بحرص قبل اتخاذ القرار، وجمع أكبر قدر ممكن من المعلو مات مع عدم تكوين النظرة الشـمولية، الاهتمام بالنظريات والتنظير على حسـاب الحقائق، إمكانية القابلية للتنبؤ و العقلانية، إمكانية التجزئة والحكم علن الأ شياء في إطار عام، والمساهمة في تو ضيح الأ شياء حتنى يمكن الوصول إلى استتاجات (سوزان يو سف وحمدي عرقوب وعبد العزيز العجمي،

$$
\begin{aligned}
& \text { 2015، ص ص-6-8). } \\
& \text { 5- التفكير الواقعي: }
\end{aligned}
$$


شــار التفكير الو اقعي هو الحقائق وهو في هذا خختلف تماماً عن التفكير التركيبـــي

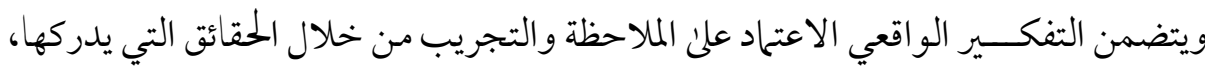

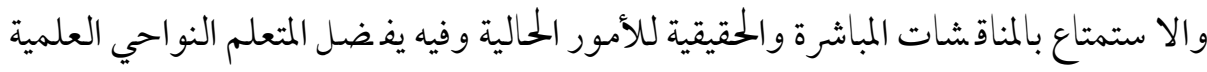

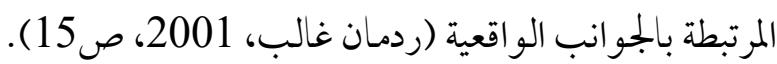
ومن أهم الدراسات السابقة التي تناولت أساليب التفكير

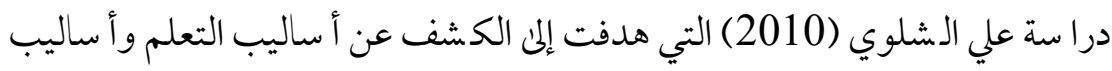

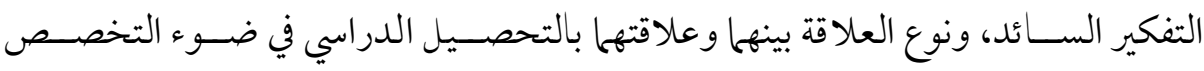

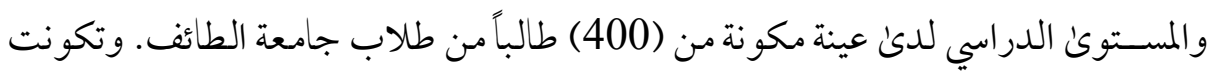
أدوات الدراسـة من قائمة أسـاليب التفكير ومقياس أسـاليب التعلم (العميق - السططحي). وتوصلت إلن جود فروق ذات دلالة إحصائية في أبعاد أساليب التفكير الرئيسية تعزئ لمتغيري

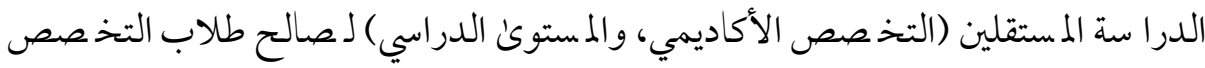
الأكاديمي العلمي، والتخصص الأكاديمي الأدبي من ذوي المستوئ (5-8) الذين يفضلون الندئ أسلوب التعلم العميق، ووجود فروق ذات دلالة إحصائية في أبعاد أساليب التفكير الرئيسية

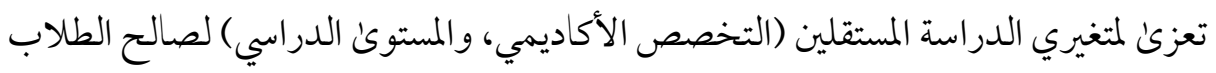

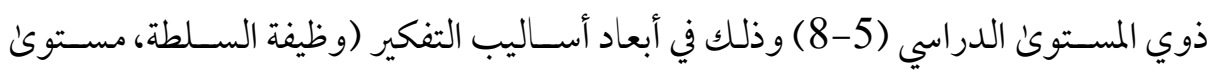
السـلطة) مقارنة بطلاب المســوى الدراسي (1-4) الذين يفضـلون أبعاد أسـاليب التفكير (النزعة إلى السلطة، مدئ السلطة).

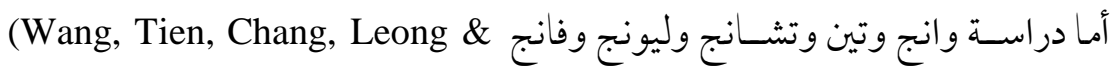
هang, 2012)

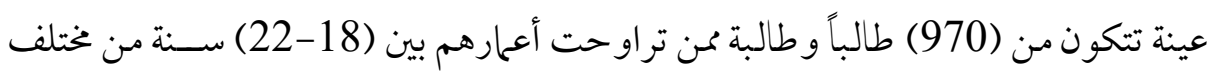


التخصصات الجامعية. وتكونت أدوات الدراسة من مقياس أساليب التفكير ومقياس السلوك التعاوني في العمل. وتو صلت الدراسة إلى أن ذوي أسلوب التفكير الإيجابي كان لديهم سلوك

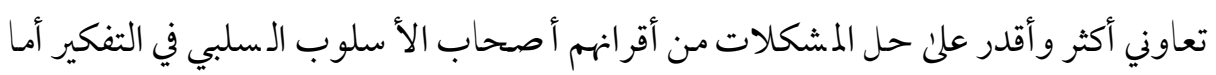

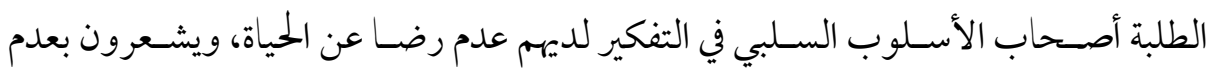
الأمل في تحقيق أهدافهم في الحياة مقارنة مع أقرانهم أصحاب الأسلوب الإيجابي في التفكير. بينما هدفت دراسـة تركي (Turki, 2012) إلى التعرف علن أسـاليب التفكير السـائدة

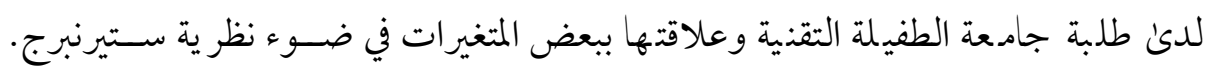
وتكونت العينة من (800) طالب وطالبة تم اختيارهم كعينة طبقية عشــو ائية وطبق عليهم

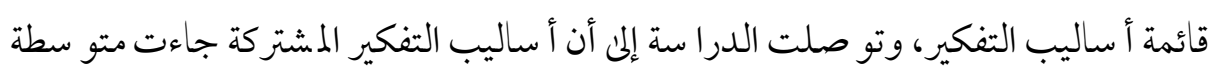

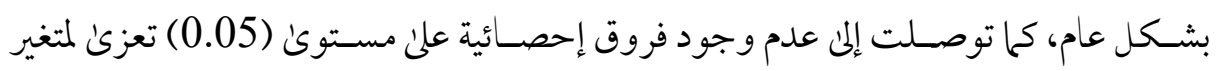

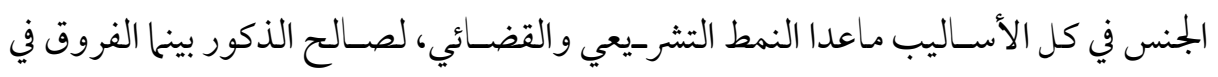

$$
\text { الأسلوب التنفيذي لصالح الإناث. }
$$

في حين أجرى فيصل الربيع وعمر شواشرة وتغريد حجازي (2014) دراسة للكشف لإثف

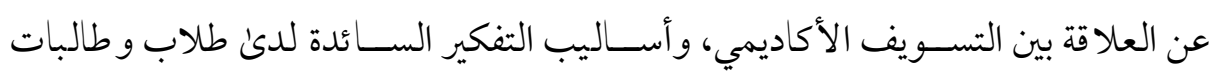
جامعتي اليرموك و العلوم والتكنولو جيا الأردنية. وتكونت عينة الدراسـة من (580) طالباً

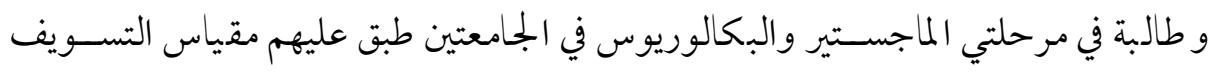

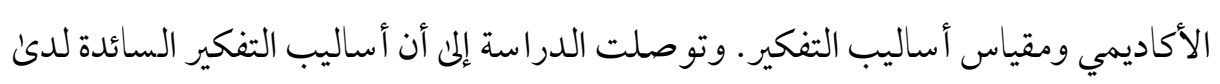

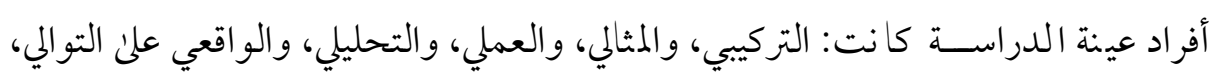

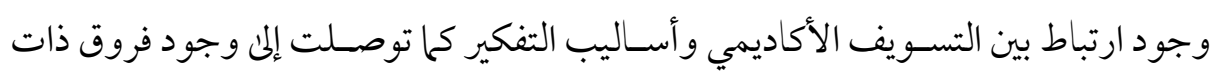
دلالة إح صائية في العلاقة بين الت سويف الأكاديمي وأ ساليب التفكير تعزئ إلم متغير الجنس والمرحلة الدراسية. 
في حين آخر هدفت دراسة نافان و شاراتماداري (Navan \& Shariatmadari, 2015) إلى معر فة العلا قة بين و ظائف أســاليب التفكير ودافعية الإنجاز الأكاديمي لدىن طلاب الماجسـتير في تخصسصـات مختلفة في جامعة إير انية. وتكونت عينة الدراسـة من (365) طالب وطالبة من طلاب الماجسـتير طبق عليهم مقياس أسـاليب التفكير . وتوصـلت الدراسـة إلى وجود علاقة موجبة بين أسـاليب التفكير التشر-يعية والتنفيذية والقضـائية مع دافعية الإنجاز

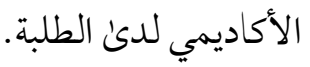
وأجرى عبد الله العنزي (2016) دراسة على (264) طالباً جامعياً بهدف الكشف عن أ ساليب التفكير ومستوى الطموح الأكاديمي ودورهما في التنبؤ بالتسويف الأكاديمي لديهم. وتكو نت أدوات الدراســة من مقياس التسـويف الأكاديمي ومقياس مســتوى الطموح الأكاديمي وقائمة أ ساليب التفكير. وتو صلت الدرا سة إلى وجود علاقة ارتباطية سلبية بين أسـاليب التفكير (التشر-يعي، التنفيذي، الحكمي، المحلي، المتحرر، الهرمي، الملكي، الأقلي، الخارجي) و التســـيف الأكاديمي، إمكانية التنبوَ بالتســويف الأكاديمي من خلال أسـاليب التفكـــر (التشريعـي والمحلي) ومتغير مستوكئ الطموح الأكاديمي في بعد (المقدرة على وضع الأهداف) والدرجة الكلية لمقياس الطموح الأكاديمي كما توصسلت إلى عدم وجود فروق دالة إحصـائياً في التســـيف الأكاديمي، وأســاليب التفكير ومســونى الطموح تعزى إلم متغير

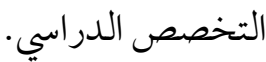
أمـا دراســة فان (Fan, 2016) هدفت إلمى معرفة أثر أســاليب التفكير في ضـــــ نظرية ستيرنبرج في فعالية الذات في صنع القرار المهني لدىن عينة مكونة من (926) طالباً جامعياً في الصـين. وتكو نت أدوات الدراسـة من مقياس أســاليب التفكير ومقياس فاعلية الذات، ومقياس اتخاذ القرار المهني. وتوصسلت إلى أن أسـاليب التفكير تلعب دوراً إيجابياً في فعالية الذات في صنع القرار المهني. 
بينما درا سة أحمد مرزوك (2016) تم إجراؤها لكشف العلاقة الارتباطية بين أساليب التفكير والاتجاهات التعصـبية عند (400) طالباً وطالبة من طلاب المرحلتين الثانية والرابعة بالكليات الإنسـانية والعلمية من طلبة جامعة بغداد. وطبق عليهم مقياس أسـاليب التفكير ومقياس الاتجاهات التعصـبية. وتوصـلت الدراســة إلى أن جميع أسـاليب التفكير لدى طلبة الجامعة أعلى من متوسط أساليب تفكير المجتمع الذي ينتمون إليه، كما توصلت إلى عدم ظهور أســاليب التفكير التركيبي والتحليلي فرو قاً ذات دلالة إحصـائية وفقاً لمتغيرات (الجنس، المرحلة، التخ صص) في حين كانت أ ساليب التفكير المثالي والعملي دالة ول صالح التخصص الإنساني ولم تظهر النتائج فروقاً ذات دلالة إحصائية بالنسبة للجنس والمرحلة، أما فيما يتعلق بأسلوب التفكير الواقعي فقد كانت النتائج دالة ولصالح التخصص الإنساني ولصالح المرحلة الرابعة وكانت غير دالة بالنسبة للجنس. كما أجرىن عبد الرحمن قشــاشــطه (2016) دراســة بهدف معرفة مصــدر الضــبط (الداخلي/ الخارجي) وعلاقته بأساليب التفكير لدىئ (100) أستاذاً وأستاذة من ثانويات دائرة حاسي خليفة بولاية الو ادي. وتكونت أدوات الدرا سة من مقياس أ ساليب التفكير، ومقياس مصدر الضبط (الداخلي/ الخارجي). وتو صلت الدرا سة إلى وجود علاقة ارتباطية سالبة بين مصـدر الضـبط الداخلي وبين أسـلوب التفكير التركيبي لدئ أسـاتذة التعليم الثانوي، وجود علاقة ارتباطية موجبة بين مـ صدر ال ضبط الداخلي وبين أ سلوب التفكير العملي لدئ أ ساتذة التعليم الثانوي، عدم وجود علاقة بين مصدر الضبط الداخلي وبين أ ساليب التفكير التحليلي والو اقعي والمثالي لدى أساتذة التعليم الثانوي، عدم وجود علاقة بين مصدر الضبط الخـارجي وبين أ ساليب التفكير الخمس لدئ أ ساتذة التعليم الثانوي، سيطرة أ سلوب التفكير المثالي ثم التحليلي لدئ أ ساتذة التعليم الثانوي بنسب شبه متساوية، وعدم وجود فروق دالة إحصائياً بين أساليب التفكير بين الأساتذة حسب متغير الجنس. 
ومن أجل الكشـف علن أسـاليب التفكير وعلاقتها بمعوقات اتخاذ القرار لدىن طلبة قسم الإر شاد النفسي في جامعة الأقصن اجرت رائدة أبو عبيد (2017) درا سة علن (210)

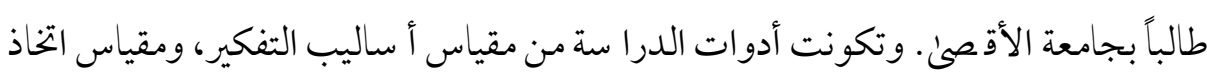

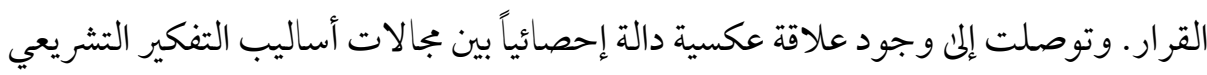
والحكمي والهرمي والعالمي ومعوقات اتخاذ القرار، وجود علاقة طردية بين الأسـلوب الملكي والأقلي والمحافظ ومعو قات اتخاذ القرار، عدم وجود فروق ذات دلالة إحصـائية لمجالات

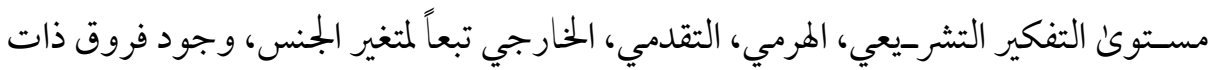

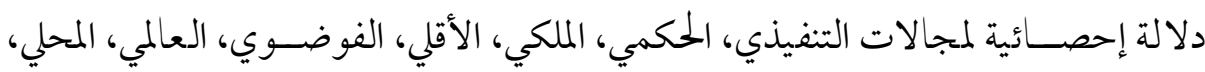
المحافظ، الداخلي تبعاً لمتغير الجنس لصالح الذكور. واجرت غادة عحمد وعلية السيد (2017) دراسة للتعرف علئ أساليب التفكير السائدة لدئ (384) طالبة من طالبات ثلاثة أق سام (المكتبات و المعلومات، الاتصال وتقنية الإعلام،

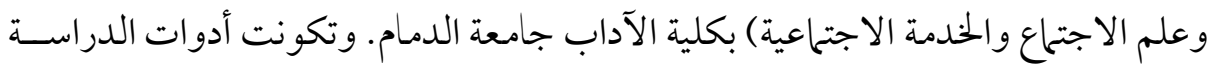
من قائمة أسـاليب التفكير لسـتيرنبرج وواجنز . وتوصـلت الدراسـة إلى أن أسـلوب التفكير

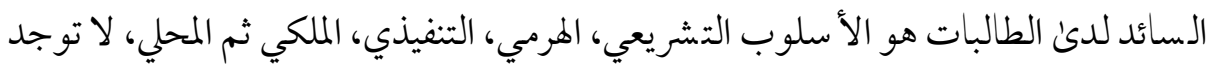
فروق معنوية في أساليب التفكير حسب متغير الفئات العمرية للطالبات. وقام طارق المصري وعلي فرح (2019) بدر اسة تهدف إلى الكشف عن مستوى دافعية

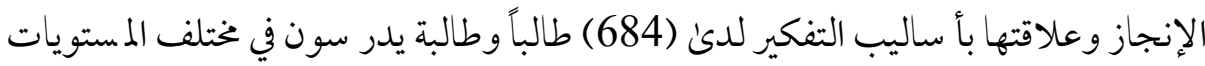
الدراسية بجامعة الملك فيصل بالمملكة العربية السعودية، وطبق عليهم مقياس دافعية الإنجاز

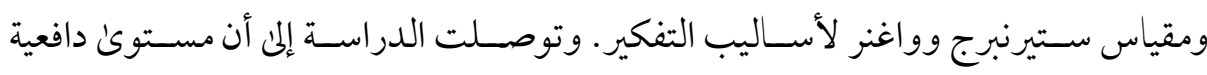

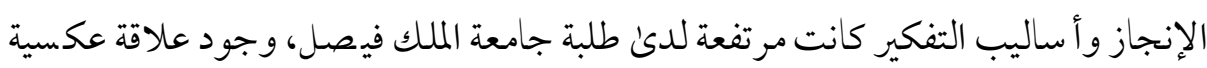


ضــيفة بين أســاليب التفكير ودافعية الإنجاز، وعدم وجود أثر للمســون الدراسي والنوع الاجتماعي في أساليب التفكير. من خلال العرض السـابق للدراسـات السـابقة التي تناولت أسـاليب التفكير اتضـحح للباحثة ما يلي: 1- تناقض بين نتائج الدراسـات فيما يخص الفروق وفقاً لمتغير التخصـص في أسـاليب التفكير. 2- تناقض بين نتائج الدراسات فيما يخص الفروق وفقاً لمتغير المرحلة في أساليب التفكير. 3- عدم وجود فروق ذات دلالة إحصـائية في أسـاليب التفكير حسـب متغير الفئات العمرية.

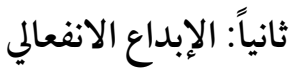

لقد تحول اهتمام الباحثين من دراســة الانفعالات على أنها معوق للعمليات العقلية المعرفية إلى دراسة الجانب الإيجابي للانفعالات وتوظيفها في علاج العديد من القضايا التي تهم الفرد في الأسرة والمجتمع وتوظيفها بشكل إيبابي في التعامل مع المشكلات الأسرية وتوظيفها في ججال المدر سة والتعليم وفي مجال العمل ومن المفاهيم التي ظهرت مركزة في جانبها التطبيقي على التعامل مع هذه القضايا نجد مفهوم الإبداع الانفعالي. ويختلف الأفراد في قدراتهم علن أن يصسبحو امبدعين انفعالياً، وهذه الفروق تفترض تو افر نفس القدرات والتي تندرج بطريقة ما تحت مفهوم الذكاء الوجداني، مع مراعاة أن كون الفرد ذكياً لا يضـمن أن يكون الفرد مبدعاً في المجال الانفعالي منه في المجال العقلي المعرفي. علاوة علن ذلك فإن الفروق الفردية في القدرات لا تفسر ـ بأي حال من الأحوال العمليات التي تنمو من خلالها الأزمات الانفعالية الحلديثة، أو تظهر الموجود. 
والمفهوم الذي يهمنا هنا هو مفهوم الإبداع الانفعالي الذي يرتبط بالذكاء الانفعلي

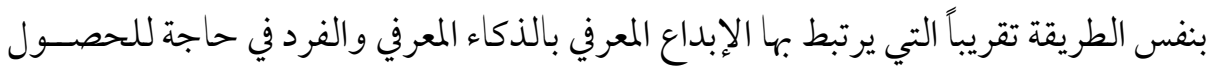

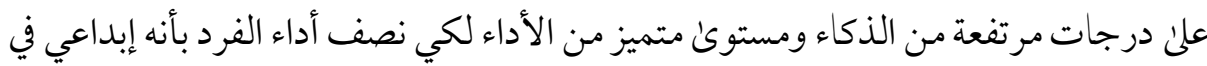
مجال معين. مع ملاحظة أن ارتفاع مستوىن الذكاء قد لا يعني أن يكون الفرد ابتكارياً.

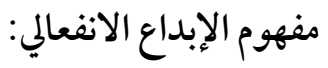
تعددت تعريفات الإبداع الانفعالي وكان من أهمها ما يلي:

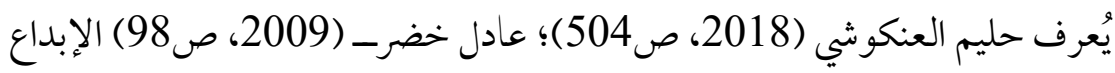

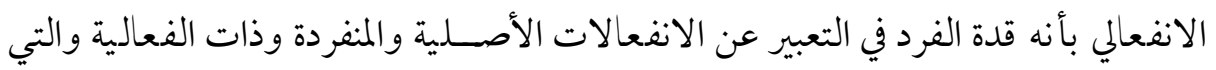

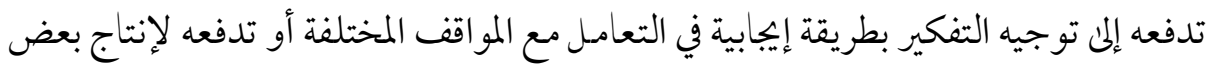

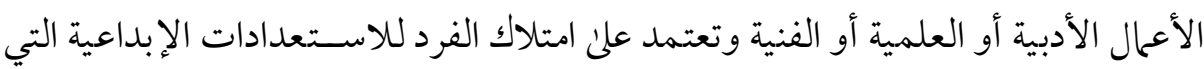
تتصف بالجدة والفعالية والأصالة. أمـاصـفاء عفيفي (2016، ص868) تُعرفه بأنه اسـتعداد الفرد لفهم الموقف الانفعلي الذي يمر به، والاستفادة من الخبرات الانفعالية السابقة الصادرة منه أو من الآخرين، والتعبير عن الانفعالات بطريقة غير مألوفة تتميز بالفعالية.

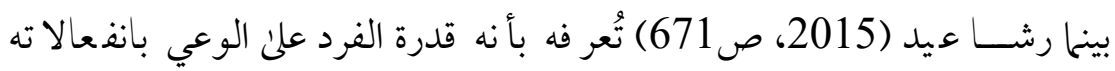

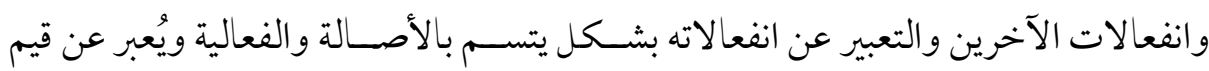

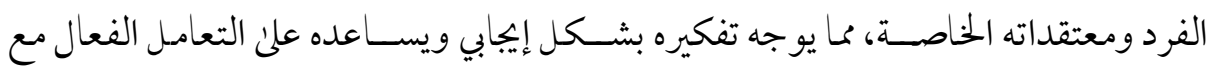
متطلبات الحياة. في حين أن بشر-كأ عمر وربيعة زيدان (2014) تُعرفه بأنه نمو للزملة الانفعالية التي

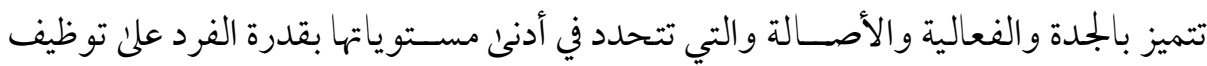


انفعالاته كما هي موجودة في المجتمع بفعالية وفي مـستو اها المتو سط بالقدرة على تعديل المعايير الخاصــة بالانفعال لتلبية حاجات الفرد والمجتمع وفي أعلى مســتو ياتها بالقدرة علن تعديل الانفعالات وو ضعها في شكل جديد وذلك بتغيير المعتقدات والمعايير الاجتحاعية التي تشكل الانفعال. ويُعر فه فتحي القلاف (2012، ص 119) بأنه قدرة الطالب علن اختبار عو اطفه والتعبير عنها بالطرق الذاتية أو النظرية من خلال اسـتـجابته على قائمة الإبداع الانفعالي أو الطرق العملية من خلال سرد الحكايات الو جدانية المرتبطة بالعواطف أو رســم الصــور الوجدانية المرتبطة بالعو اطف التي تعزز نموه الشخصي وعلاقاته الاجتتاعية بالآخرين. ومحمد البحيري (2012، ص374) عر فه بأنه قدرة واسـتعداد الفرد على التعبير الأصـــل عن الانفعالات، و المشــاعر بصــور متفردة، ومرنة، وفعالة، تعكس القيم والقو اعد والخبرات الو جدانية والاجتتاعية، وتســاعده في التعامـل مع المواقف الحياتية، ومشـكلاته الوجدانية والمجتمعية بفاعلية. بينحا تُعر فه زينب بدوي (2011، ص184) بأنه قدرة الفرد علن إظهار أنواع من بن الانفعالات، تتميز بالتفرد و الأصالة ويتكون من أربعة مكونات أساسية هي: (1) الطلاقة الانفعالية: وتعبر عند عدد الأفكار الانفعالية التي ينتجها المسـتجيب علن المشكلات الانفعالية.

المرونة الانفعالية: وتدور حول عدد فئات الأفكار الانفعالية التي ينتجها المسـتجيب

$$
\text { عند حل المشكلات الانفعالية. }
$$

إدراك التفصـيل: وتشـير إلى قدرة الفرد علن أنه وصـف التغيرات الانفعالية وقر اءة

$$
\text { التعابير الانفعالية بدقة، وإيجاد الترابط بينها في المواقف المختلفة. }
$$


(4) الفعالية الانفعالية: وتعني قدرة الفردعلن إنتاج الأفكار الانفعالية ذات المنفعة للفرد

$$
\text { والمجتمع. }
$$

وتُعرفه عواطف صالح (2007، ص ص149) بأنه تلك الأنشطة الانفعالية التي يقوم بها

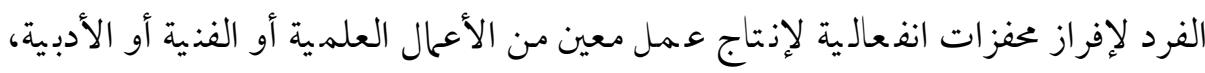

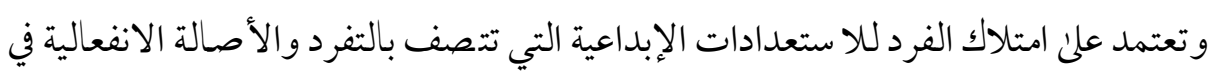
إنتاج الأعمال الإبداعية. من خلال التعريفات السابقة اتضح للباحثة ما يلي:

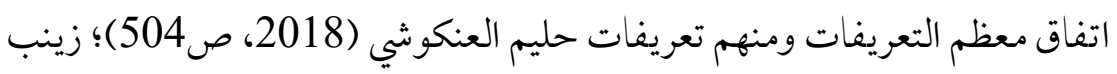

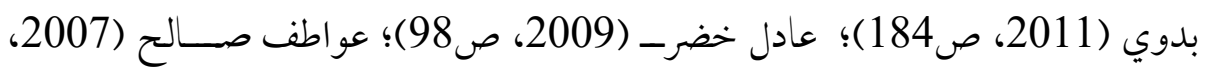

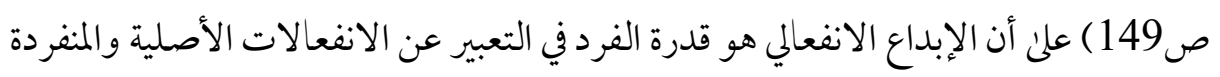

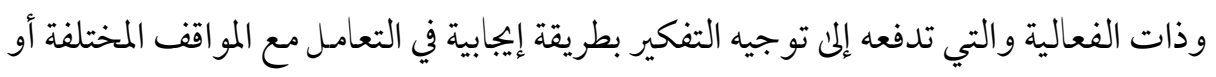

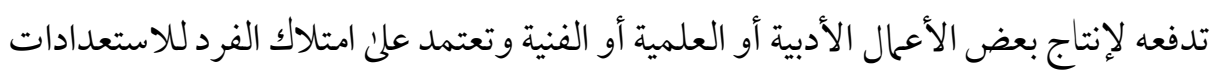
الإبداعية التي تتصف بالجدة والفعالية والأصالة.

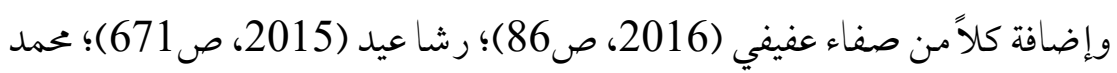

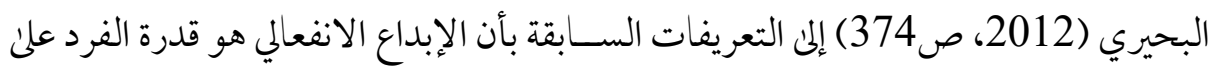

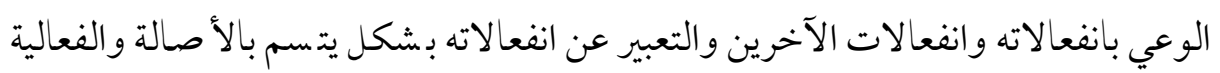

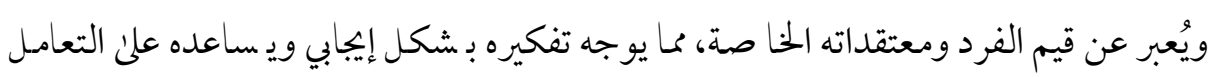
مع المو اقف الحياتية، ومشكلاته الوجدانية والمجتمعية بفاعلية. في حين أن بشركن عمر وربيعة زيدان (2014) قامت بتعريفه بأنه نمو للزملة الانفعالية

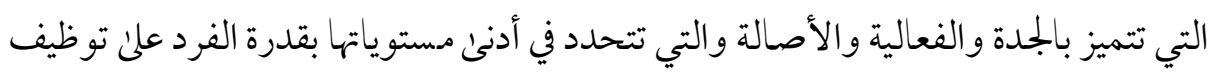
انفعالاته كما هي موجودة في المجتمع بفعالية وفي مستو اهـا المتو سط بالقدرة على تعديل المعايير 
الخاصسة بالانفعال لتلبية حاجات الفرد والمجتمع وفي أعلى مسـتو ياتها بالقدرة علن تعديل الانفعالات وو ضعها في شكل جديد وذلك بتغيير المعتقدات والمعايير الاجتحاعية التي تشكل الانفعال. أمـا فتحي القلاف (2012، ص 119) عر فه بأنه قدرة الطالب على اختبار عو اطفه و التعبير عنها بالطرق الذاتية أو النظرية من خلال اسـتجابته على قائمة الإبداع الانفعالي أو الطرق العملية من خلال سرد الحكايات الو جدانية المرتبطة بالعواطف أو رســم الصــور الوجدانية المرتبطة بالعواطف التي تعزز نموه الشخصي وعلاقاته الاجتتاعية بالآخرين.

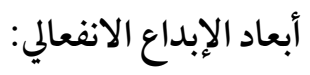
تتلخص أبعاد الإبداع الانفعالي التي يتناولها البحث الحالي فيها يلي: 1- الاستعداد أو التهيؤ الانفعالي:

وي شير إلى فهم الفرد لانفعالاته وانفعالات الآخرين في الأحداث المختلفة، وقد تكون هذه المرحلة طويلة المدىئ أو قصـيرة المدئ ويتوقف ذلك على قدرة الأفراد، فالأفراد الذين

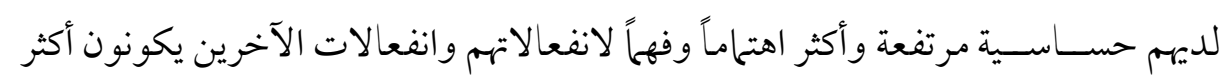
كفاعة في الاسـتعداد أو التهيؤ الانفعالي والبحث عن إمكانية توظيف الانفعالات والمشــاعر ومن ثم فإن الاسـتعداد أو التهيؤ الانفعالي يشـير إلى القدرة على تجميع واسـتيعاب وفهم المعلومات المســمدة من الانفعالات و إمكانية توظيفها في توجيه التفكير والأفعال (حسـني

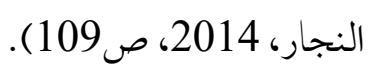
2- 2 - 2 الجدة الانفعالية:

وتشـيـر الجلدة إلى قدرة الفرد علن إنتاج اسـتجابات انفعالية في سـياق اجتهاعي جديد وغير مألوف عن السـياق الاجتماعي النمطي المرتبط بالاسـتجابة النمطية أو الســائدة في 
المجتمع، وتتحدد الجحدة من خلال أحد المعايير الثلاثة التالية: مقارنة الاستجابة الر اهنة للفرد

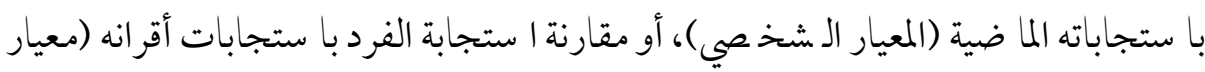

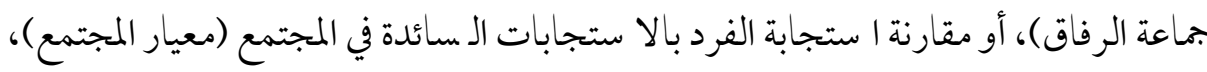

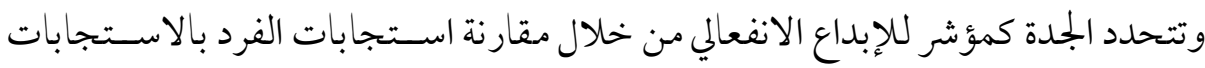

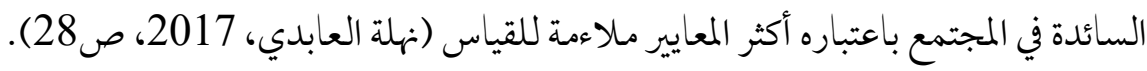
3- الفعالية الانفعالية:

كل ا ستجابة جديدة وغتلفة لكي تكون إبداعية ييب أن تكون ذات قيمة وفائدة للفرد

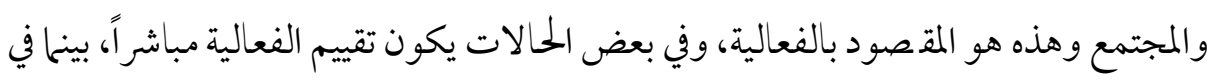

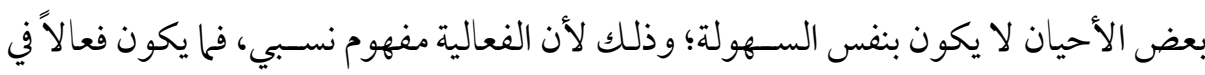

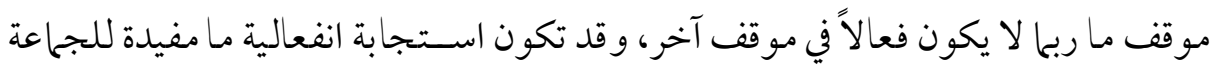

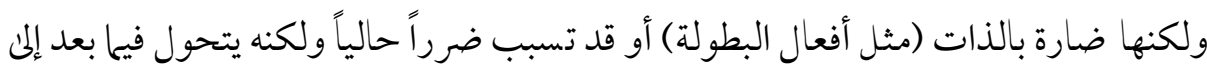

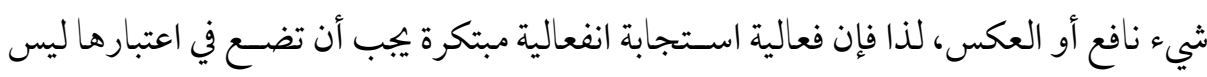

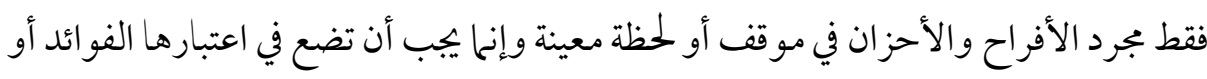

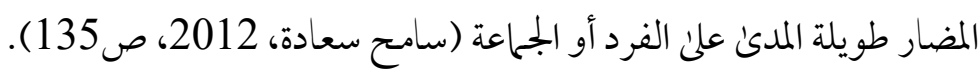

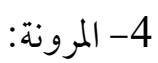

وهــي الق_ـدرة علـــئ التعبير عـــن الحالة الانفعالية بأسـلوب إيمابي بحيث يمكن

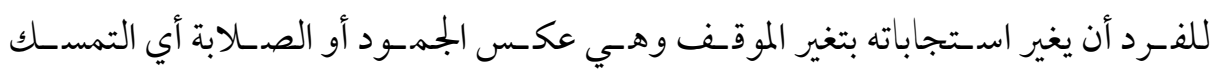

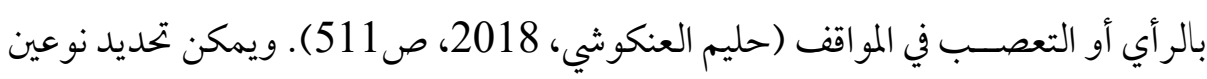

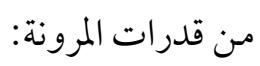




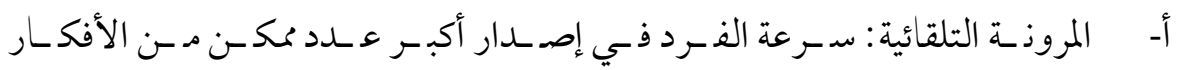

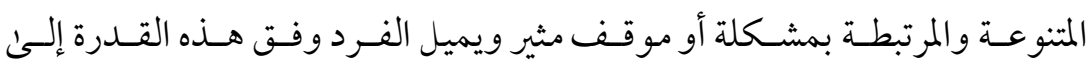
المبـادرة التلقائية في المو اقف ولا يكتفي بمجرد الاستجابة.

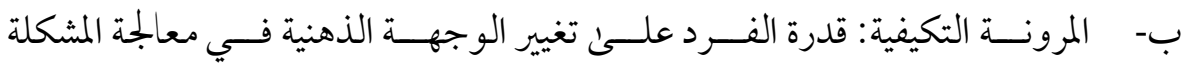

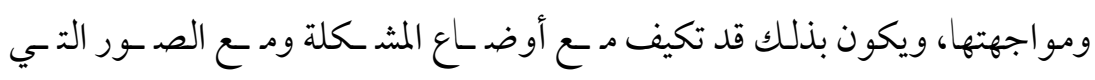
تأخــهـا أو تظهر بها المشكلة (بشرى عمر وربيعة زيدان، 2014، ص 286).

\section{خصائص الأشخاص المبدعين انفعالياً:}

يتميز الأفراد المبدعون انفعالياً بأنهم حسـاسـون انفعالياً، يهتمون بانفعالاتهم ويعطون لها قيمة كبيرة، يحاولون فهم تفاعلاتهم الانفعالية، يسـطيعون توليد اسـتجابات انفعالية غير شـائعة، يسـتمتعون بالمواقف التي يكون فيها انفعالات غير عادية، حسـاســون لكيفية تأثير انفعالاتهم في الآخرين، يوصلون انفعالاتهم بطريقة جيدة، يشرحون انفعالاتهم بصدق، أفضل في التعبير عن انفعالاتهم بشكل رمزي، يتعمقون في توضيح معنى تعبيراتهم الانفعالية، يعطون اعتباراً كبيراً للتفكير في مششاعر و سلوك الآخرين؛ يستطيعون القيام بتقييمات معقدة، يكونون

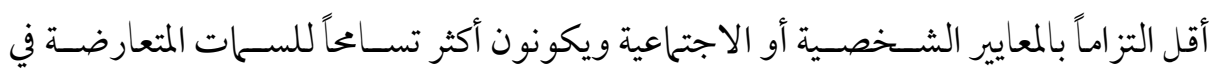
أنفسهم والآخرين، يجدون تحدياً عندما ينظر إليه الآخرون باعتباره تهديداً، يقدرون انفعالات ومشـاعر الآخرين، ومتفتحين علن الخبرة (صسفاء عفيفي، 2016، ص ص292-93؛ إبر اهيم أحمد، 2008، ص ص20-21؛ سامح سعادة، 2012، ص ص137-138). ومن الدراسات السابقة التي تناولت الإبداع الانفعالي دراســة ريهام بركات (2016) التي هدفت إلى التعرف علن طبيعة العلاقة بين الإبداع الانفعلي وأسـاليب المواجهة لدئ (200) طالباً و طالبة بكليتي الفنون التطبيقية والتربية 
بجامعة بنها، وتراوحت أعمارهم بين (19-22) عاماً. وتكونت أدوات الدراسـة من مقياس

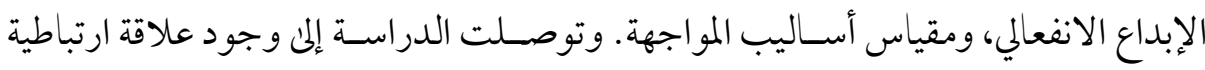
موجبة ذات دلالة إحصائية بين درجات الطلاب علن مقياس الإبداع الانفعالي ودرجاتهم علن

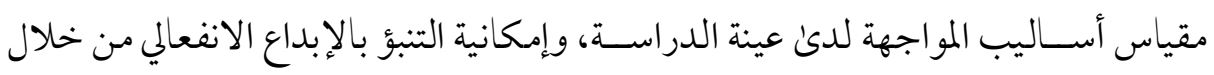
الأساليب التو افقية السوية للمواجهة. أما دراسة شامة وماثير (Shama \& Mathyr, 2016) هدفت إلى الكشف عن العلاقة بين الأمل والإبداع الانفعالي لدئ عينة تتكون من (300) طالب جامعي من مجالات مختلفة

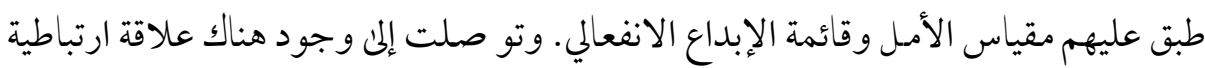
موجبة بين الأمل و الإبداع الانفعلي. بينما قامت رشا عيد (2015) بإجراء دراسة للتعرف علئ العلاقة بين الابتكار الانفعالي

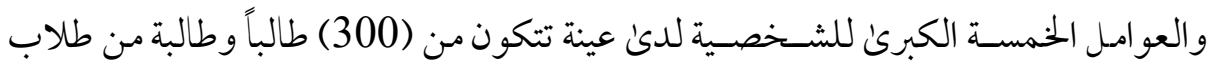

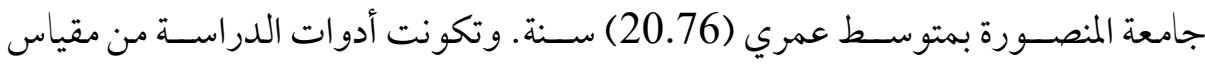

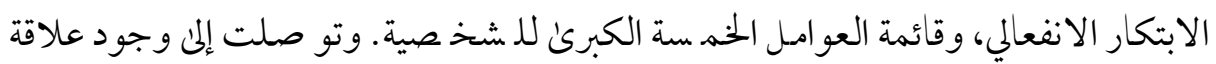

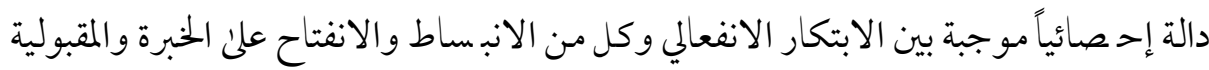
ويقظة الضمير، وجود علاقة دالة إحصائية سالبة بين الابتكار الانفعلي والعصابية، وإمكانية التبؤ بالابتكار الانفعالي من خلال الانبساط و الانفتاح على الخبرة والعصابية.

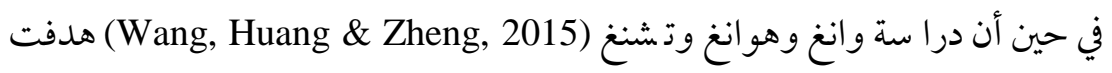

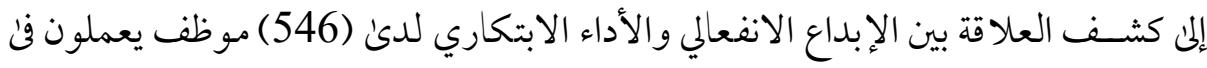
18 شركة في الصين. وتكونت أدوات الدراسة من مقياس الإبداع الانفعالي، ومقياس الدافعية الداخلية، واختبار الأداء الابتكاري. الدراسـة إلى أن الإبداع الانفعالي لدئ الموظفين له تأثير 
كبير علن أدائهم الابتكاري، وأن الدافعية الداخلية تلعب دوراً وسـيطاً في العلاقة بين الإبداع الانفعالي والأداء الابتكاري.

(Soroa, Gorostiaga, في حين آخر هدفت سوروا، غورو ستياغا، أريزيتا وبالويركا Arizeta \& Balluerka, 2015) الانفعالي لدى' عينة تتكون من (1145) طالب جامعي منهم (650) أنثى، و(495) ذكر. وتكونت أدوات الدراسة من قائمة الإبداع الانفعالي. وتوصلت إلى أن القائمة تتكون من ثلاثة عو امل هم (الا ستعداد - الجلدة- الفعالية أو الأ صالة)، وأن القائمة تت سم أبعادها بالات ساق

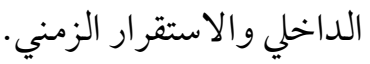
وللكشف عن العلاقة بين الإبداع الانفعالي وكل من فعالية الذات الانفعالية ومهارات اتحاذ القرار والنموذج البنائي بينهم لدى' (322) طالباً وطالبة من طلاب الكليات الأدبية و العلمية بجامعة كفر الشـيخ قام حسـني النجار (2014) بدراسـة وطبق فيها قائمة الإبداع الانفعالي، ومقياس فعالية الذات الانفعالية، ومقياس مهارات اتحاذ القرار ـ وتو صل إلى وجود تأثير دال إحصائياً لكل من التخصص (علمي - أدبي) والنوع (ذكور - إناث) وتنفاعلاتها في الإبداع الانفعالي وكانت الفروق لصالح الإناث ولصالح طلاب التخصص الأدبي، ووجود

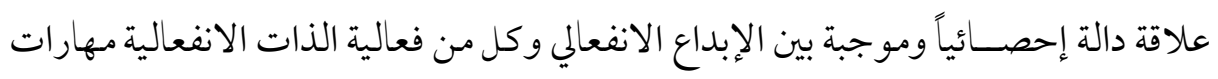
اتحاذ القرار، وإمكانية التبؤ بمهارات اتحاذ القرار من خلال كل من الإبداع الانفعالي وفعالية الذات الانفعالية. أما دراسة بشرى عمر وربيعة زيدان (2014) هدفت الدراسة إلى التعرف علن مستوى الإبداع الانفعالي لدى' عينة تتكون من (380) طالباً وطالبة من جامعة تكريت. وتكو نت أدوات الدراســة من مقياس الإبداع الانفعالي. وتوصــلت إلى وجود مســتوى إبداع انفعالي منخفض لدى عينة الدراسـة، عدم وجود فروق ذات دلالة إحصـائية بين الذكور والإناث في 
الإبداع الانفعالي، وعدم وجود فروق ذات دلالة إحصائية بين التخصص العلمي والإزساني

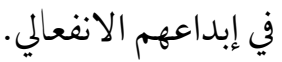
بينما هدفت دراسة ربيعة الحمداني (2014) إلى التعرف علن مستوئ الإبداع الانفعلي،

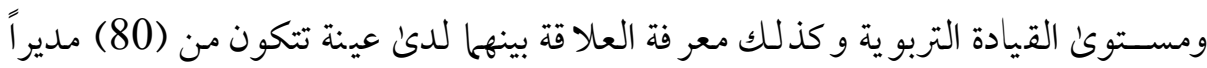
ومديرة من مدراء المدارس الثانوية. وتكونت أدوات الدراسـة من مقياس الإبداع الانفعالي، مدي، ومقياس مسـتوى القيادة التربوية. وتوصسلت إلن وجودمسـتوى متدني من الإبداع الانفعلي والقيادة التربوية لدن مدراء المدارس الثانوية، ووجود علاقة ارتباطية إيمابية بين كل من الإبداع الانفعالي والقيادة التربوية. في حين أن دراســة زاري (Zareie, 2014) هد فت إلى كشـف العلا قة بين الإبداع

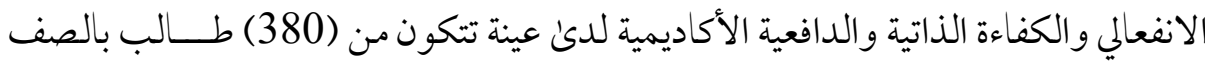
الثالث بمدارس شـسبستار . وتكونت أدوات الدراسـة من قائمة الإبداع الانفعالي، واسـتبيان الكفاءة الذاتية، واسـتبيان لدافعية الأكاديمية. وتوصسلت إلى وجود علاقة ارتباطية دالة بين

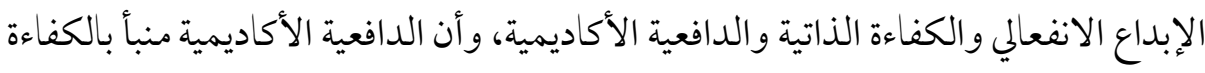
الذاتية والإبداع الانفعلي. في حين آخر هدفت دراسـة سـامح ســادة (2012) إلى تمييز الابتكار الانفعلي عن

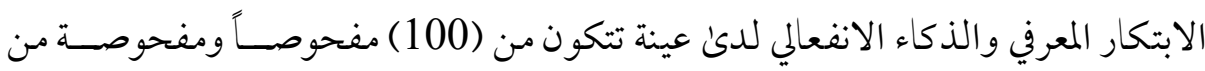

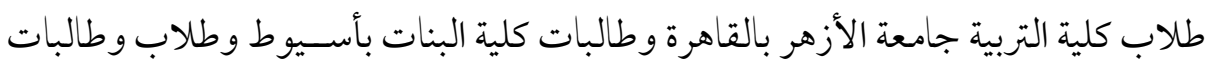

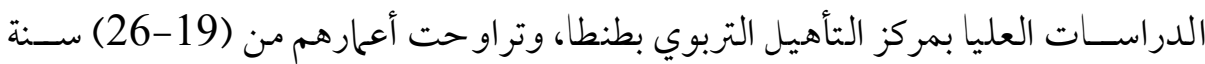
بمتو سط قدره (22) سنة. وتكونت أدوات الدرا سة من مقياس الابتكار الانفعلي، واختبار القدرة علن التفكير الابتكاري، ومقياس الذكاء الانفعالي. وتوصسلت إلن وجود فروق دالة إحصـائياً ين متوســات الذكـــــور والإناث في الابتكار الانفعلي والذكاء الانفعالي لصـالح 
الإناث، عدم وجود فروق دالة إحصـائياً ين متوسـطات الذكور والإناث في الابتكار المعرفي،

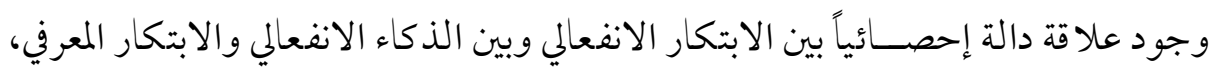
و إمكانية التنبؤ بالابتكار الانفعالي من خلال الابتكار المعرفي. وأجرت زينب بدوي (2011) دراســة بهدف التعرف على أفضـلـل نموذج بنائي للعلاقات والتأثيرات المباشرة وغير المباشرة والكلية بين المتغيرات: الإبداع الانفعالي، والذكاء الانفعالي، والانتباه الانفعالي، والتفكير الانفعالي. وتكونت عينة الدراسـة من (394) طالبًاً و طالبة في الفر قة الرابعة بكلية التربية بالإسـاعيلية طبق عليهم مقياس الإبداع الانفعالي، ومقياس الذكاء الانفعالي، ومقياس الانتباه الانفعالي، ومقياس التفكير الانفعالي. وتوصـلت إلى وجود تأثير موجب مباشر وغير مباشر وكلي للذكاء الانفعالي في الإبداع الانفعالي، والتفكير الانفعالي، والانتباه الانفعالي، ووجود تأثير كلي للذكاء الانفعالي في مكونات الإبداع الانفعالي والتفكير الانفعالي.

كما اجريت درا سة نيـــزديان وعابدي (Nezhdyan \& Adbi, 2010) لو صف البناء العاملي لقائمة الإبداع الانفعالي لأفـريل (1999) لدئ عينة تتكون من (650) طالبا إيرانيا في جامعة طهر ان. وتكو نت أدوات الدراســة من قائمة الإبداع الانفعالي لأفر يل (1999). وتوصـلت إلى أن قائمة الإبداع الانفعالي تتكون من ثلاثة عو امل هم الاسـتعداد أي (الفهم و التعلم من مشـاعر المرء والآخرين)، الجلدة وهي (القدرة علن تجربة المشـاعر غير الاعتيادية) والفاعلية / الأصالة وهي (المهارة في التعبير عن المشاعر بصدق وبصراحة). من خلال العرض السابق للدراسات السابقة اتضح للباحثة ما يلي: 1- عدم وجود فروق ذات دلالة إح صائية بين طلاب التخ صص العلمي والإذ ساني في الإبداع الانفعلي. 


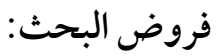

من خلال عرض الدراسات السابقة يمكن صياغة فروض البحث التالية:

1- - تتباين أساليب التفكير لدئ طلاب كلية التربية.

2- مستوى الإبداع الانفعالي لدى طلاب كلية التربية متوسط.

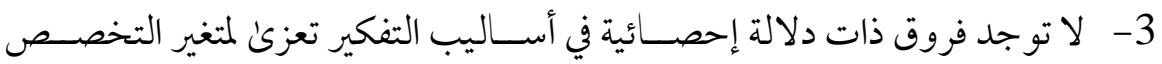

$$
\text { الدراسي (علمي / أدبي). }
$$

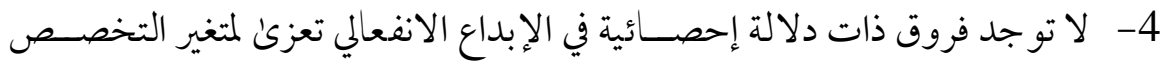

$$
\text { الدراسي (علمي / أدبي). }
$$

5- لا توجد فروق ذات دلالة إحصـائية في أسـاليب التفكير تعزئ لمتغير مكان السـكن

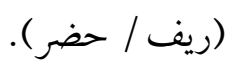

6- تو جد فروق ذات دلالة إحصــائية في الإبداع الانفعلي تعزئ لمتغير مـكان السـكن

$$
\text { (ريف / حضر ) لصالح الحضر. }
$$

7- توجد علاقة دالة إحصـائياً بين أسـاليب التفكير والإبداع الانفعالي لدئ طلاب كلية

$$
\text { التربية. }
$$

8- تشـكل أسـاليب التفكير نموذج تنبؤي دال إحصـائياً بأبعاد الإبداع الانفعالي لدين

$$
\text { طلاب كلية التربية. }
$$




\section{المنهج و الطريقة والإجر اءات: - ات \\ 1}

اعتمدت الباحثة في البحث الحالي علن المنهج الوصـفي الارتباطي، لكو نه المنهج

المناسب لطبيعة البحث ومتغيراته.

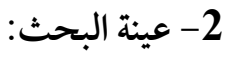

تكو نت عينة الدراسـة من (180) طالباً جامعياً بالفرقة الرابعة بكلية التربية جامعة

دمياط موزعين كما بجدول (1):

$$
\text { جدول (1) يبين عينة البحث }
$$

\begin{tabular}{|c|c|c|c|c|}
\hline \multicolumn{2}{|c|}{ مكان السكن } & \multicolumn{2}{|c|}{ التخصص } & \multirow{2}{*}{ المتغير } \\
\hline حضر & ريف & أدبي & علمي & \\
\hline 86 & 94 & 102 & 78 & العدد \\
\hline \multicolumn{4}{|c|}{180} & المجموع \\
\hline
\end{tabular}

لجمع المعلومات والبيانات اللازمة لاختبار فروض البحث، تم اسـتخدام الأدوات

$$
\begin{aligned}
& \text { (1) مقياس أساليب التفكير (إعداد: الباحثة): } \\
& \text { 1) وصف المقياس: }
\end{aligned}
$$

يتكون المقياس من (20) موقفاً متبو عة بخمس عبارات مختلفة تمثل كل عبارة حلاً

لذلك الموقف، حيث يعبر كل حل عن أحد أسـاليب التفكير الخمســة (التركيبي، والعملي، والو اقعي، والتحليلي، والمثلي)، والمطلوب مسن الطالب أن يضع أرقامَاً تتراوح من (1-5) أمـام العبارات حيث يضــع در جة (5) للعبارة الأكثر انطباقاً عليه ثم در جة (4) للعبارة الأدنى 
انطباقاً ودر جة (3) للعبارة التي تأتي بعدها بالانطباق ودر جة (2) للعبارة الأقل انطباقاً

$$
\text { 2) ودرجة (1) للعبارة التي لا تنطبق. } 1 \text { (1) الاتصائص السيكومترية للمقياس: }
$$

تم حسـاب معاملات الارتباط بين درجة كل بعد من أبعاد المقياس والدر جة الكلية

للمقياس، وذلك لمعر فة مدئ ارتباط البعد بالدر جة الكلية للمقياس، وذلك للتحقق من

\begin{tabular}{|c|c|c|}
\hline مستوى الدلالة & معامل الارتباط & الأبعاد \\
\hline 0.05 & 0.25 & التركيبي \\
\hline 0.01 & 0.28 & المثالي \\
\hline 0.01 & 0.31 & العملي \\
\hline 0.01 & 0.29 & التحليلي \\
\hline 0.05 & 0.22 & الواقعي \\
\hline
\end{tabular}

$$
\text { الاتساق الداخلي للمقياس، ويتضح بجدول (2) قيم معاملات الارتباط: }
$$

جدول (2) معاملات الارتباط بين الأبعاد الخمسة لمقياس أساليب التفكير والدرجة الكلية للمقياس

تبين من جدول (2) أن الأبعاد الخمســة تتمتع بمعاملات ارتباط قوية ودالة إحصـائياً حيث تراو حت معاملات الارتباط بين (0.22 - 0.31)، و هذا يدل على أن أبعاد مقياس

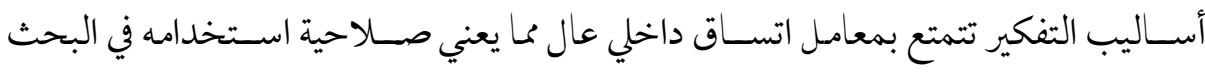

أ- الصــدق الظاهري: تم عرض المقياس علن مجموعة من المحكمين المتخصـصـين في العلوم التربو ية والنفسـية و عددهم عشرسة خبراء، وبعد أخذ بعض الملاحظات والتو جيهات من 
الأسـاتذة المحكمين اسـتخرجت النسـبة المئوية لكل فقرة إذ حصـلت أقل فقرة علن مـا نسـبته (90\%) و حصلت أعلى فقرة علن نسبة (100٪) وبذلك يكون المقياس مكوناً من (20) موقفاً

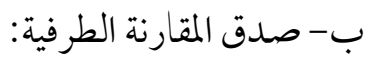
قامت الباحثة بحساب صدق المقياس من خلال استخدام صدق المقارنة الطرفية الذي يقوم على حسـاب دلالة الفروق بين متوسـطات درجات الأفر اد ذوي الدرجات المرتفعة على المقياس ومتوسـطات درجات الأفراد ذوي الدر جات المنخفضسة علن نفس المقياس، ويبين

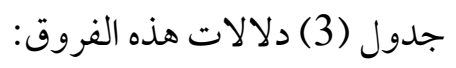

جدول (3) دلالة الفروق بين مرتفعي ومنخفضي الدرجات علن مقياس أساليب التفكير

\begin{tabular}{|c|c|c|c|c|c|}
\hline مستوى الدلالة & "قيمة & الانحر اف & المتوسط & المجموعات & الأبعاد \\
\hline \multirow{2}{*}{0.001} & \multirow{2}{*}{$16.91-$} & 4.10 & 53.00 & منخفضي الدرجات & \multirow{2}{*}{ التركيبي } \\
\hline & & 3.48 & 71.54 & مرتفعي الدرجات & \\
\hline \multirow{2}{*}{0.01} & \multirow{2}{*}{$3.13-$} & 5.71 & 58.96 & منخفضي الدرجات & \multirow{2}{*}{ المثالي } \\
\hline & & 6.35 & 64.42 & مرتفعي الدرجات & \\
\hline \multirow{2}{*}{0.001} & \multirow{2}{*}{$15.64-$} & 3.48 & 47.67 & منخفضي الدرجات & \multirow{2}{*}{ العملي } \\
\hline & & 4.11 & 64.88 & مرتفعي الدرجات & \\
\hline \multirow{2}{*}{0.001} & \multirow{2}{*}{$16.19-$} & 3.27 & 53.38 & منخفضي الدرجات & \multirow{2}{*}{ التحليلي } \\
\hline & & 3.08 & 68.21 & مرتفعي الدرجات & \\
\hline \multirow{2}{*}{0.001} & \multirow{2}{*}{$14.57-$} & 4.41 & 46.46 & منخفضي الدرجات & \multirow{2}{*}{ الو اقعي } \\
\hline & & 4.18 & 64.54 & مرتفعي الدرجات & \\
\hline
\end{tabular}


يدل علن أن المقياس يميز بين الأفراد ذوي الدرجات العليا والأفراد ذوي الدرجات الدنيا في

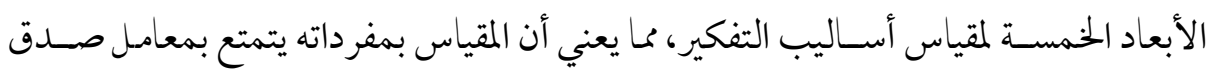
عال. وهذا يشير إلى صلاحية المقياس للتمييز بين الدرجات العليا والدرجات المنخفضة. 3. بات المقياس:

تم حسـاب معامل ثبات المقياس باسـتخدام طريقة ألف كرونباخ، و كانت كما يبينها

جدول (4)

$$
\text { جدول (4) قيم معاملات الثبات بطريقة ألفاكرونباخ }
$$

\begin{tabular}{|c|c|}
\hline قيمة ألف كرونباخ & أسلوب التفكير \\
\hline 0.58 & التركيبي \\
\hline 0.52 & المثلي \\
\hline 0.51 & العملي \\
\hline 0.51 & التحليلي \\
\hline 0.57 & الواقعي \\
\hline 0.60 & المقياس ككل \\
\hline
\end{tabular}

وهذا يعني ثبات المقياس وإمكانية استخدامه بالبحث الحالي.

(2) مقياس الإبداع الانفعالي (إعداد: الباحثة):

1) وصف المقياس:

يتكون المقياس من (40) مفردة أما كلاً منها خمس بدائل هم (موافق بشـدة - موافق -

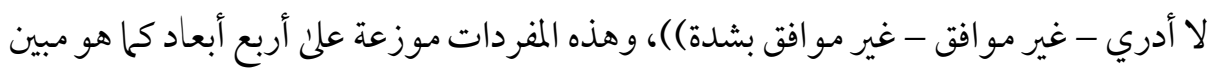

بجدول (5):

http://dx.doi.org/10.29009/ijres.3.2.10 
جدول (5) يبين توزيع مفردات المقياس علن أبعاده

\begin{tabular}{|c|c|c|}
\hline أرقام المفردات & البعد ال & p \\
\hline $10-1$ & الاستعداد أو التهيؤ الانفعلي & 1 \\
\hline $20-11$ & 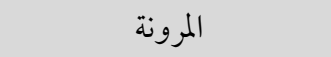 & 2 \\
\hline $30-21$ & الجلدة & 3 \\
\hline $40-31$ & الفعالية & 4 \\
\hline
\end{tabular}

2) الخصائص السيكومترية للمقياس:

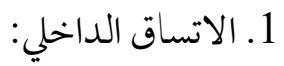

تم حسـاب معاملات الارتباط بين درجة كل بعد من أبعاد المقياس والدر جة الكلية

للمقياس، وذلك لمعر فة مدئ ارتباط البعد بالدر جة الكلية للمقياس، وذلك للتحقق من الاتساق الداخلي للمقياس، ويتضح بجدول (6) قيم معاملات الارتباط:

جدول (6) معاملات الارتباط بين الأبعاد الأربعة لمقياس الإبداع الانفعالي والدرجة الكلية للمقياس

\begin{tabular}{|c|c|c|}
\hline مستوى الدلالة & معامل الارتباط & الأبعاد \\
\hline 0.001 & 0.74 & الاستعداد أو التهيؤ الانفعالي \\
\hline 0.001 & 0.77 & 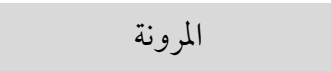 \\
\hline 0.001 & 0.79 & الجدة \\
\hline 0.001 & 0.79 & الفعالية \\
\hline
\end{tabular}

تبين من جدول (6) أن الأبعاد الأربعة تتمتع بمعاملات ارتباط قوية ودالة إحصـائياً حيث تراو حت معاملات الارتباط بين (0.74 - 0.79)، و هذا يدل علن أن أبعاد مقياس الإبداع الانفعالي تتمتع بمعامل اتسـاق داخلي عال مما يعني صــلاحية اسـتخدامه في البحث 
أ- الصدق الظاهري: تم عرض المقياس علن مجموعة من المحكمين المتخصصين في العلوم

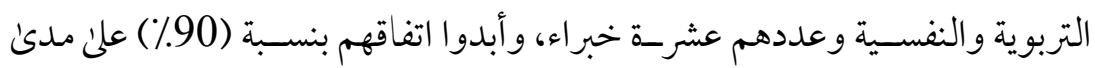
مناسـبة مفردات المقياس للهدف الذي تقيسـه ولأبعاده وللعينة وللمرحلة العمرية

$$
\text { و البيئة التي سيتم التطبيق فيها. }
$$

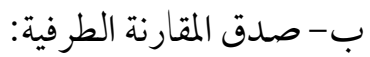

قامت الباحثة بحساب صدق المقياس من خلال استخدام صدق المقارنة الطرفية الذي يقوم على حسـاب دلالة الفروق بين متوسـطات درجات الأفر اد ذوي الدرجات المرتفعة على الن المقياس ومتوســطات درجات الأفراد ذوي الدر جات المنخفضــة على نفس المقياس، ويبين

$$
\text { جدول (7) دلالات هذه الفروق: }
$$

\begin{tabular}{|c|c|c|c|c|c|}
\hline مستوى الدلالة & "ت" & الانحراف & المتوسط & المجموعات & 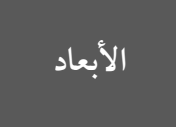 \\
\hline \multirow{2}{*}{0.001} & \multirow{2}{*}{$15.91-$} & 2.62 & 36.21 & منخفضي الدرجات & \multirow{2}{*}{ الاستعداد أو } \\
\hline & & 1.52 & 46.04 & مرتفعي الدرجات & \\
\hline \multirow{2}{*}{0.001} & \multirow{2}{*}{$19.42-$} & 2.80 & 31.21 & منخفضي الدرجات & \multirow{2}{*}{ المرونة } \\
\hline & & 1.89 & 44.58 & مرتفعي الدرجات & \\
\hline \multirow{2}{*}{0.001} & \multirow{2}{*}{$19.18-$} & 2.75 & 30.25 & منخفضي الدرجات & \multirow{2}{*}{ الجلدة } \\
\hline & & 2.20 & 44.04 & مرتفعي الدرجات & \\
\hline \multirow{2}{*}{0.001} & \multirow{2}{*}{$18.24-$} & 2.89 & 32.63 & منخفضي الدرجات & \multirow{2}{*}{ الفعالية } \\
\hline & & 1.86 & 45.42 & مرتفعي الدرجات & \\
\hline \multirow{2}{*}{0.001} & \multirow{2}{*}{$17.55-$} & 7.51 & 137.33 & منخفضي الدرجات & \multirow{2}{*}{ الدرجة الكلية } \\
\hline & & 7.61 & 175.63 & مرتفعي الدرجات & \\
\hline
\end{tabular}

جدول (7) دلالة الفروق بين مرتفعي ومنخفضي الدرجات علن مقياس الإبداع الانفعلي 
يتبين من جدول (7) وجود فروق جوهر ية دالة إحصــائياً بين الدر جات العليا والدرجات الدنيا في الأبعاد الأربعة لمقياس الإبداع الانفعالي لصـالح الدرجات العليا، وهذا يدل علن أن المقياس يميز بين الأفر اد ذوي الدرجات العليا والأفراد ذوي الدرجات الدنيا في الأبعاد الأربعة لمقياس الإبداع الانفعالي، مما يعني أن المقياس بمفرداته يتمتع بمعامل صــدق عال. وهذا يشير إلى صلاحية المقياس للتمييز بين الدرجات العليا والدرجات المنخفضة. 3. ثبات المقياس: - n

تم حسـاب معامل ثبات المقياس باسـتخدام طريقة ألف كرونباخ، وكانت كما يبينها

جدول (8) (8) (2) (2)

جدول (8) قيم معاملات الثبات بطريقة ألف كرونباخ

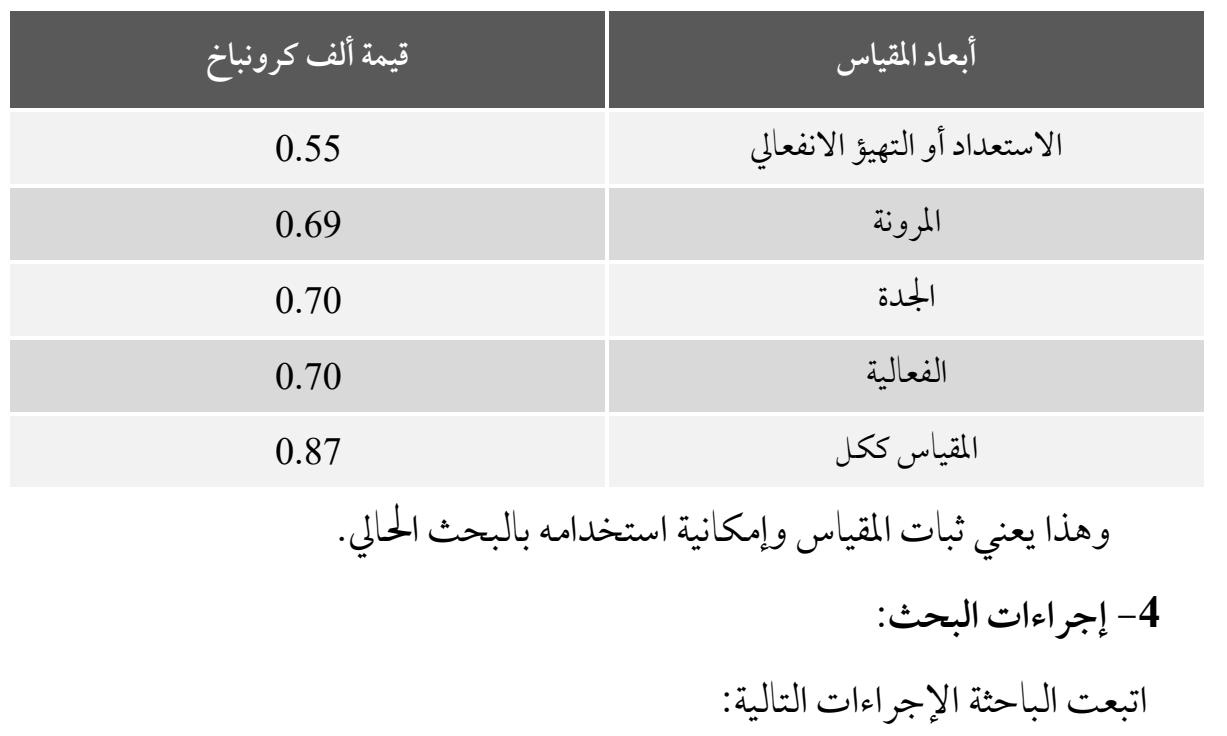

(1) الاطلاع على الأدبيات المرتبطة بموضـوع البحث من إطار نظري ودراسـات سـابقة ومعالجتها بما يتناسب مع أهداف البحث.

(2) إعداد أدوات البحث و التحقق من خصائصها السيكومترية. 
(3) تحديد ججتمع البحث وهم طلاب الفرقة الرابعة بكلية التربية جامعة دمياط. (4) اختيار عينة البحث وبلغ عددهم (180) طالباً وطالبة بالفرقة الرابعة بكلية التربية جامعة دمياط. (5) تطبيق مقياس أساليب التفكير على عينة البحث. (6) تطبيق مقياس الإبداع الانفعلي على عينة البحث.

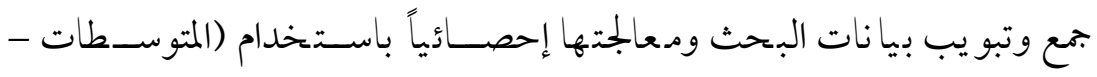

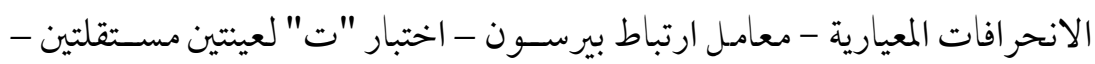

$$
\text { تعادلة الانحدار ) لاختبار فروض البحث. }
$$

\section{نتائج الفرض الأول وتفسيرها ومناقشتها:}

ينص الفرض الأول علن أن: تتباين أساليب التفكير لدئ طلاب كلية التربية، وللتحقق من صحة هذا الفرض، تم حساب المتوسطات الحسابية والانحر افات المعيارية لأداء أفراد عينة الدراسة علن مقياس أساليب التفكير. ويوضح جدول (9) تلك القيم.

\begin{tabular}{|c|c|c|}
\hline الانحر اف المعياري & المتوسط الحسابي & أساليب التفكير \\
\hline 7.58 & 62.47 & التركيبي \\
\hline 7.97 & 64.46 & المثالي \\
\hline 7.06 & 55.76 & العملي \\
\hline 6.13 & 60.59 & التحليلي \\
\hline 7.52 & 55.66 & الو اقعي \\
\hline
\end{tabular}
جدول (9) المتوسطات الحسابية والانحرافات المعيارية لأداء أفراد عينة الدراسة علن مقياس أساليب التفكير 
يتبين من جدول (9) أن الفرض الأول تحقق وذلك أن أسـاليب التفكير تختلف بين أفر اد عينة الدراسة كالتالي: نجد في أعلى ترتيب أسلوب التفكير المثلي ثم يليه أسلوب التفكير التركيبي ثم أسلوب التفكير التحليلي ثم أسلوب التفكير العملي ثم أسلوب التفكير الواقعي. وهذا يعني أن طلاب الجامعة يميلون بدر جة أكبر إلى تكوين وجهات نظر خختلفة تجاه الأشـياء ويميلون إلى التوجيه المسـتقبلي والتفكير في الأهداف و الاهتحام باحتياجاتهم وما هو مفيد بالنسـبة لهم ويركزوا الاهتحام علئ ما هو مفيد للناس والمجتمع ومحور الاهتحام هو القيم، ويميلون بدرجة كبيرة إلى التو اصل لبناء أفكار جديدة وأصلية مختلفة تماماً عما يفعله الآخرون في القدرة علن تركيب الأفكار المختلفة والتطلع إلى بعض وجهات النظر، ويعتمدون بم ستوىن متوسط على الملاحظة والإدراك من خلال الحواس، والحقائق التي يدركها. ويمكن تف سير اختلاف ترتيب أ ساليب التفكير في هذا البحث عن غيره من الأبحاث بأن أسـلوب التفكير المتبع عند التعامـل مع المو اقف الاجتماعية في الجموانب الحياتية قد يختلف عن أ سلوب التفكير عند حل المسائل العلمية مما يعني أن الفرد قد يـ ستخدم عدة أ ساليب في التفكير قد تتغير هذه الأساليب مع الزمن، كما أنها يمكن أن تعود إلى اختلاف المجتمعات التي أجر يت فيها هذه الدراســات، حيث تختلف طبيعة تفكير كل مجتمع عن المجتمع الآخر، واختلاف العوامل التي تؤثر في التفكير، وأيضـاً يمكن تفســرها باختلاف المناهج الدراسـية التي تعرض هلا هؤلاء الأفراد، وفيها إذا كانت تركز على تنمية أسـلوب تفكير معين أكثر من

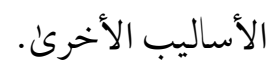

نتائج الفرض الثاني وتفسيرها ومناقشتها: ينص الفرض الثاني على أن: مســوى الإبداع الانفعالي لدى طلاب الجامعة متوسـط. وللتحقق من صـحة هذا الفرض، تم جمع درجات عبارات المقياس ككل ثم مقارنتها بالقيمة 
المتو سطة لها، وحيث أن عدد مفردات هذا المقياس (40) مفردة، و القيمة المتو سطة للاستجابة على العبارة تســاوي (3) فتكون القيمة المتوسـطة لاسـتجابات المقياس ككل (120) درجة، وتعبر عن المتو سط الافتراضي لهذا المقياس. كما تم حساب ذلك أيضاً على الأبعاد الأربعة التي يتكون منها المقياس، ويو ضح جدول (10) دلالة الفروق بين المتو سط التجريبي لا ستجابات طلاب الجـامعة والمتوسـط الافتراضي لاسـتجاباتهم علن مفردات المقياس ككل وعلن الأبعاد

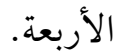

جدول (10) دلالة الفروق بين المتوسط التجريبي لاستجابات طلاب الجامعة والمتوسط الافتراضي لاستجاباتهم علن مفردات المقياس ككل وعلن الأبعاد الأربعة

\begin{tabular}{|c|c|c|c|c|c|c|}
\hline مستوى & قيمة & الحرجية & الالحعراف & المتوسط & الافتراضي & المجالات \\
\hline 0.001 & 26.22 & 179 & 4.06 & 41.23 & 30 & الاستعداد أو التهيؤ \\
\hline 0.001 & 14.04 & 179 & 5.45 & 38.07 & 30 & المرونة \\
\hline 0.001 & 12.49 & 179 & 5.53 & 37.28 & 30 & الجلدة \\
\hline 0.001 & 16.71 & 179 & 5.20 & 39.17 & 30 & الفعالية \\
\hline 0.001 & 21.59 & 179 & 15.71 & 155.74 & 120 & المقياس ككل \\
\hline
\end{tabular}

و هذه النتيجة تتفق مع دراســة نهلة العابدي (2017)، وتختلف مع دراســة كلاً من بشرى عمر وربيعة زيدان (2014)؛ وربيعة الحمداني (2014) وتعزي الباحثة هذه النتيجة إلى أن طلاب الجامعة نظر اً لأهمية المرحلة التي يلتحقون بها يهتمون بانفعالاتهم ويعطون لها قيمة كبيرة، يوصسلون انفعالاتهم بطريقة جيدة، يشر-حون 
انفعالاتهم بصدق، يتعمقون في توضيح معنى تعبيراتهم الانفعالية، يقدرون انفعالات ومشاعر

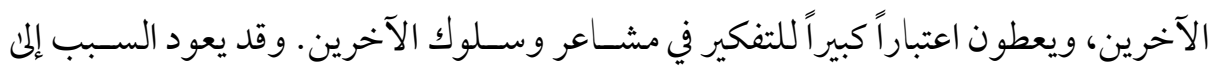
أ ساليب التنشئة الاجتماعية أو الأسرية التي تطبع الفرد في اكت ساب اللغة والعادات و التقاليد والقيم والأعراف الاجتماعية التي تبدأ من الأسرة وتنتقل معه إلى المجتمع.

نتائج الفرض الثالث وتفسيرها ومناقشتها: ينص الفرض الثالث على أن: لا تو جد فروق ذات دلالة إحصـائية في أسـاليب التفكير تعزئ لمتغير التخصص الدراسي (علمي / أدبي). وللتحقق من صحة هذا الفرض تم حساب قيمة (ت) ودلالتها الإحصائية بين متوسطات درجات طلاب التخصص العلمي ومتوسطات درجات طلاب التخصص الأدبي في أساليب التفكير وجدول (11) يوضح هذه الفروق ودلالتها. جدول (11) الفروق بين متوسطات درجات طلاب التخصص العلمي ومتوسطات درجات طلاب التخصص الأدبي في أساليب التفكير

\begin{tabular}{|c|c|c|c|c|c|c|}
\hline \multirow{2}{*}{ مستوى الدلالة } & \multirow{2}{*}{ قيمة "ت" } & \multicolumn{2}{|c|}{ أدبي (ن = 102) } & \multicolumn{2}{|c|}{ علمي (ن=78) } & \multirow{2}{*}{ المجتموعات } \\
\hline & & $\varepsilon$ & $p$ & $\varepsilon$ & p & \\
\hline غير دال & 0.78 & 7.80 & 61.92 & 7.04 & 63.18 & التركيبي \\
\hline غير دال & $0.13-$ & 8.40 & 64.55 & 7.49 & 64.33 & المثلي \\
\hline غير دال & 0.35 & 7.63 & 55.53 & 6.33 & 56.05 & العملي \\
\hline غير دال & 0.42 & 5.75 & 60.35 & 6.66 & 60.90 & التحليلي \\
\hline غير دال & $0.72-$ & 7.13 & 56.16 & 8.04 & 55.00 & الواقعي \\
\hline
\end{tabular}

يتضـح من جدول (11) أنه لا توجد فروق ذات دلالة إحصـائية في أسـاليب التفكير تعزئ لمتغير التخصص الدراسي (علمي / أدبي)، وبناء عليه تم قبول الفرض الثالث. وتتفق هذه النتيجة مع دراسة كلاً من عبد الله العنزي (2016)؛ محمد كادي (2016)، وتختلف مع دراسة كلاً من علي الشلوي (2010)؛ أحمد مرزوك (2016). 
وترجع الباحثة ما توصسل إليه هذا البحث إلى أن المرجعية الثقافية والبيئية والتربوية للطلاب تكاد تكون واحدة بالإضـافة إلى أنهم يخضسعون إلمان نظام تعليمي واحد في في كل أبعاده

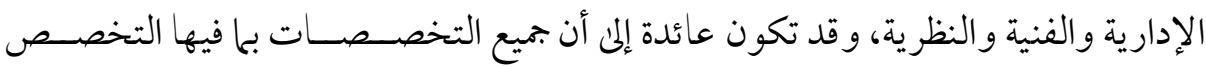

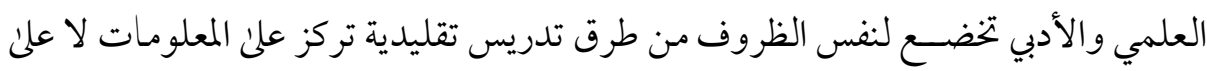
المهارات والاعتماد علن المحاضرة التي يكون فيها الطالب هو المستقبل للمعلومة دون إتاحة الفرصة له بأن يكون محللاً وموظفاً لأساليب التفكير في العملية التعليمية.

\section{نتائج الفرض الرابع وتفسيرها ومناقشتها:} ينص الفرض الرابع علن أن: لاتوجد فروق ذات دلالة إحصسائية في الإبداع الانفعالي تعزىن لمتغير التخصص الدراسي (علمي / أدبي). وللتحقق من صحة هذا الفرض تم حساب قيمة (ت) ترون ودلالتها الإحصائية يين متوسطات درجات طلاب التخصص العلمي ومتوسطات درجات طلاب

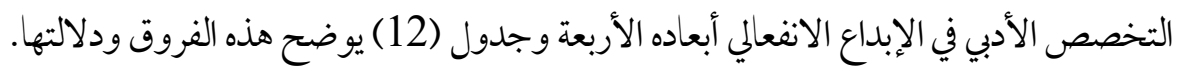
جدول (12) الفروق بين متوسطات درجات طلاب التخصص العلمي ومتوسطات درجات طلاب التخصص الأدبي في الإبداع الانفعالي وأبعاده

\begin{tabular}{|c|c|c|c|c|c|c|}
\hline \multirow{2}{*}{ مستوى } & \multirow{2}{*}{ قيمة "ت" } & \multicolumn{2}{|c|}{ أدبي (ن = 102) } & \multicolumn{2}{|c|}{ علمي (ن=78) } & \multirow{2}{*}{ المتغموعات } \\
\hline & & $\varepsilon$ & $p$ & $\varepsilon$ & p & \\
\hline غير دال & 0.15 & 3.53 & 41.18 & 4.72 & 41.31 & الاستعـداد الاو \\
\hline غير دال & $1.16-$ & 4.87 & 38.65 & 6.11 & 37.031 & المرونة \\
\hline غير دال & $1.18-$ & 5.34 & 38.18 & 5.61 & 36.10 & الجدة \\
\hline 0.05 & $2.02-$ & 4.75 & 40.12 & 5.56 & 37.92 & الفعالية \\
\hline غير دال & $1.66-$ & 14.35 & 158.12 & 17.02 & 152.64 & المقياس ككل \\
\hline
\end{tabular}


يتضـح من جدول (12) أنه لا توجد فروق ذات دلالة إحصـائية في الإبداع الانفعالي و أبعاده (الاسـتعداد أو التهيؤ الانفعالي - المرونة - الجدة) تعزئ لمتغير التخصـص الدراسي (علمي / أدبي)، بينما في بعد الفعالية توجد فروق ذات دلالة إحصـائية لصـالح التخصـص الأدبي وبناءاً عليه تم قبول الفرض الرابع جزئياً. وتتفق هذه النتيجة مع دراسـة بشركئ عمر وربيعة زيدان (2014)، وتتفق جزئياً مع دراسة محمد أبو راسين (2015)، وتختلف مع دراسة كلاً من حسني النجار (2014) وتعزي الباحثة هذه النتيجة إلى أن كلا طلاب التخصــصـين يتشــابه الخبرات التي يكتسبو ها في الحياة الجامعية بسبب خضو عهم لنظام واحد في التعليم ويتعر ضون إلى المؤثرات البيئية نفسها. أمـا بالنســبة لتفوق طلاب التخصـصص الأدبي علن العلمي في بعد الفعالية فقط نتيجة لطبيعة دراستـهم التي تجعلهم أكثر انفتاحاً علن المجتمع مما يمكنهم من التعامل مع انفعالاتهم بطريقة تجعلهم أكثر سيطرة علن المو اقف و أكثر تفاعلاً مع الآخرين. نتائج الفرض الخامس وتفسيرها ومناقشتها: ينص الفرض الخامس علن أن: لا توجد فروق ذات دلالة إحصائية في أساليب التفكير تعزئ لمتغير مكان السكن (ريف / حضر) . وللتحقق من صحة هذا الفرض تم حساب قيمة (ت) ودلالتها الإحصائية بين متو سطات درجات طلاب الريف ومتو سطات درجات طلاب الحضر في أساليب التفكير وجدول (13) يوضح هذه الفروق ودلالتها. 
جدول (13) الفروق بين متوسطات درجات طلاب الريف ومتوسطات درجات طلاب الحضر في أساليب التفكير

\begin{tabular}{|c|c|c|c|c|c|c|}
\hline \multirow{2}{*}{ الدلالة } & \multirow{2}{*}{ قيمة "ت" } & \multicolumn{2}{|c|}{ الحضر (ن = 86) } & \multicolumn{2}{|c|}{ الريف (ن=94) } & المجموعات \\
\hline & & $\varepsilon$ & $\rho$ & $\varepsilon$ & $\rho$ & المتغيرات \\
\hline غير دال & 1.24 & 8.20 & 62.28 & 7.49 & 62.64 & التركيبي \\
\hline غير دال & $0.58-$ & 7.30 & 63.34 & 7.74 & 65.45 & المثالي \\
\hline غير دال & 1.22 & 6.17 & 56.21 & 6.89 & 55.34 & العملي \\
\hline غير دال & $0.72-$ & 6.58 & 59.77 & 6.06 & 61.34 & التحليلي \\
\hline غير دال & 1.17 & 11.61 & 56.26 & 8.32 & 55.11 & الواقعي \\
\hline
\end{tabular}

يتضسح من جدول (13) أنه لا توجد فروق ذات دلالة إحصـائية في أسـاليب التفكير تعزئ لمتغير مكان السكن (ريف / حضر)، وبناء عليه تم قبول الفرض الخامس. وتعزي الباحثة هذه النتيجة إلى أن جميع الطلاب يخضـعون إلى نظام تعليمي واحد في كل أبعاده الإدارية و الفنية والنظرية، يخضـعون لنفس الظروف من طرق تدريس تقليدية تركز على المعلومات لا على المهارات والاعتماد على المحاضرة التي يكون فيها الطالب هو المسـتقبل للمعلو مة دون إتا حة الفرصــة له بأن يكون محلالًا وموظفاً لأســاليب التفكير في العملية التعليمية.

\section{نتائج الفرض السادس وتفسيرها ومناقشتها:} ينص الفرض ال سادس علن أن: توجد فروق ذات دلالة إح صائية في الإبداع الانفعالي تعزى لمتغير مكان السكن (ريف / حضر) لصالح الحضر . وللتحقق من صحة هذا الفرض تم حساب قيمة (ت) ودلالتها الإحصائية بين متو سطات د درجات طلاب الريف ومتو سطات درجات طلاب الحخر في الإبداع الانفعلي أبعاده الأربعة وجدول (14) يو ضح هذه الفروق 
جدول (14) الفروق بين متوسطات درجات طلاب الريف ومتوسطات درجات طلاب الحضر في الإبداع الانفعالي وأبعاده

\begin{tabular}{|c|c|c|c|c|c|c|}
\hline \multirow{2}{*}{ الدلالة } & \multirow{2}{*}{ قيمة "ت" } & \multicolumn{2}{|c|}{ الحضر (ن = 86) } & \multicolumn{2}{|c|}{ الريف (ن=94) } & \multirow{2}{*}{ المجمموعات } \\
\hline & & $\varepsilon$ & $p$ & $\varepsilon$ & $p$ & \\
\hline غير دال & $0.10_{-}$ & 4.01 & 41.28 & 4.16 & 41.19 & الاستعداد أو \\
\hline غير دال & $0.47-$ & 5.18 & 38.35 & 5.73 & 37.81 & المرونة \\
\hline غير دال & $0.76-$ & 5.86 & 37.74 & 5.23 & 36.85 & الجلدة \\
\hline غير دال & $0.64-$ & 5.09 & 39.53 & 5.34 & 38.83 & الفعالية \\
\hline غير دال & $0.67-$ & 16.39 & 156.91 & 15.15 & 154.68 & المقياس ككل \\
\hline
\end{tabular}

يتضـحسح من جدول (14) أنه لا توجد فروق ذات دلالة إحصـائية في الإبداع الانفعالي وجميع أبعاده تعزئ لمتغير مـكان السـكن (ريف / حضر-)، وبناء عليه تم رفض الفرض السادس.

وتعزي الباحثة هذه النتيجة إلى أن أفر اد العينة يعيشـون في دولة واحدة ســواء كانوا سـكان ريف أو حضر-ويتلقون نفس المناهج ويخضـعون إلى نظام تعليمي واحد في كل أبعاده الإدارية والفنية والنظرية مما ينعكس علن القدرات الإبداعية لديهم.

نتائج الفرض السابع وتفسيرها ومناقشتها: ينص الفرض السابع على أن: توجد علاقة دالة إحصائياً بين أساليب التفكير والإبداع الانفعالي لدى طلاب الجامعة. وللتحقق من صـسحة هذا الفرض تم اسـتخدام معامل ارتباط بيرسون، وجدول (15) يوضح ذلك: 
جدول (15) معاملات الارتباط بين أساليب التفكير والإبداع الانفعلي

\begin{tabular}{|c|c|c|c|c|c|}
\hline الإبداع الانفعالي ككل & 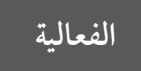 & 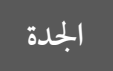 & 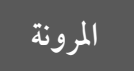 & الاستعداد & المتغيرات \\
\hline 0.02 & 0.05 & $0.01-$ & 0.00 & 0.00 & التركيبي \\
\hline $0.19-$ & $0.16-$ & $0.17-$ & $0.12-$ & $0.14-$ & 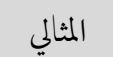 \\
\hline *** 0.36 & $* * 0.32$ & $* 0.25$ & ***0.27 & $* * 0.30$ & 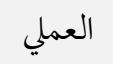 \\
\hline 0.04 & $0.07-$ & 0.03 & $0.03-$ & $* 0.23$ & 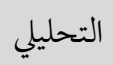 \\
\hline $0.03-$ & $0.05-$ & 0.07 & $0.01-$ & $0.15-$ & الو اقعي \\
\hline \multicolumn{6}{|c|}{ ق*دالة عند 0.05 ق*** دالة عند 0.01} \\
\hline
\end{tabular}

يتضح من جدول (15) أنه:

1- لا توجد علاقة ارتباطية بين التفكير التركيبي والإبداع الانفعالي وكل أبعاده.

2- لا توجد علاقة ارتباطية بين التفكير المثالي والإبداع الانفعالي وكل أبعاده.

3- تو جد علاقة ارتباطية دالة إحصـائياً بين التفكير العملي والإبداع الانفعالي و كل

أبعاده.

4- لا توجد علاقة ارتباطية بين التفكير التحليلي والإبداع الانفعالي وأبعاده الثلاثة التالية

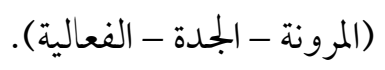

5- لا تو جد علاقة ارتباطية بين التفكير الو اقعي والإبداع الانفعالي وكل أبعاده.

$$
\text { وبناء عليه تم قبول الفرض السابع جزئياً. }
$$

وتفسر - الباحثة تلك النتيجة بأن الأفراد من ذوي أسـلوب التفكير العملي يميلون إلى

إيجاد طرائق جديدة للقيام بالأشـياء بها هو متوفر لديهم من أدوات كما يمتاز سـلوكهم بالمرونة

و القدرة علن التكيف، وهذه السمات يتسم بها أيضاً الأفراد المبدعين، وأيضًاً الأفراد العمليون 
يميلون لأن يخظو برضــا الآخرين أو قبو لهم على الأقل وهذه سـمة من أهم ســات المبدعين انفعالياً، ومن هنا يتضح سبب العلاقة الارتباطية بين التفكير العملي والإبداع الانفعالي.

نتائج الفرض الثامن وتفسيرها ومناقشتها: ينص الفرض الثامن على أن: تشكل أساليب التفكير نموذج تنبؤي دال إحصائياً بأبعاد الإبداع الانفعالي لدئ طلاب الجمامعة. ولاختبار هذا الفرض اسـتخدمت الباحثة تحليل الاذحدار المتعدد خطوة بخطوة؛ حيث تم إد خال متغير التفكير العملي في خطوة وحيدة لتشـكيل نموذج وحيد للتنبؤ بأبعاد الإبداع الانفعالي وكذلك الدرجة الكلية، ويبين جداول (16) تحليل الاذحدار المتعدد خطوة بخطوة للتفكير العملي علن أبعاد الإ بداع الانفعالي

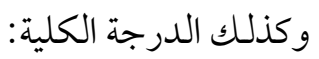
جدول (16): تحليل الانحدار المتعدد المتدرج للتفكير العملي علن أبعاد الإبداع الانفعلي

\begin{tabular}{|c|c|c|c|}
\hline الدلالة الإحصائية & قيمة (ف) & البعد البع & p \\
\hline 0.01 & 8.80 & الاستعداد أو التهيؤ الانفعالي & 1 \\
\hline 0.01 & 6.85 & 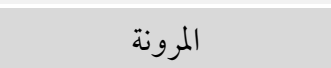 & 2 \\
\hline 0.05 & 5.61 & الجدة الجدة & 3 \\
\hline 0.01 & 10.00 & الفعالية & 4 \\
\hline 0.001 & 13.37 & الإبداع الانفعلي ككل & 5 \\
\hline
\end{tabular}

يتضـحسح من جداول (16) إمكانية التنبؤ بأبعاد الإبداع الانفعالي (الاسـتعداد أو التهيؤ الانفعالي - المرونة - الجلدة - الفعالية) و كذلك الدرجة الكلية من خلال التفكير العملي. وتبين الجداول أر قام: (17)، (18)، (19)، (20)، و(21) مـ (21) وعاملات الاذحدار المعيارية للتفكير العملي ومسـتون دلالتها للتنبؤ بأبعاد الإبداع الانفعالي (الاستعداد أو التهيؤ الانفعالي - المرونة - الجلدة - الفعالية) وكذلك الدرجة الكلية 
جدول (17): معاملات الانحدار المعيارية للتفكير العملي للتنبؤ ببعد الاستعداد أو التهيؤ الانفعالي

\begin{tabular}{|c|c|c|c|c|c|c|}
\hline \multirow{2}{*}{ مستوى الدلالة } & \multirow{2}{*}{ قيمة } & \multicolumn{2}{|c|}{ معامل الانحدار غير المعياري } & \multirow{2}{*}{ معامل الانحدار } & \multirow{2}{*}{ 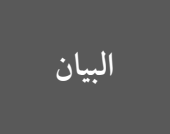 } & \multirow{2}{*}{ 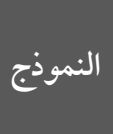 } \\
\hline & & الخطأ المعياري & B & & & \\
\hline 0.001 & 9.60 & 3.29 & 31.56 & \multirow{2}{*}{0.30} & الثابت & \multirow{2}{*}{1} \\
\hline 0.01 & 2.97 & 0.06 & 0.17 & & التفكير العملي & \\
\hline \multicolumn{7}{|c|}{ جدول (18): معاملات الانحدار المعيارية للتفكير العملي للتنبؤ ببعد المرونة } \\
\hline 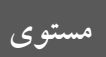 & قيمة ق ق ق & \multicolumn{2}{|c|}{ معامل الانحدار غير المعياري } & معامل الانحدار & \multirow{2}{*}{ 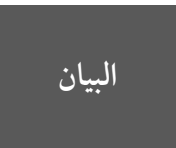 } & \multirow{2}{*}{ النموذج } \\
\hline 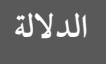 & (ت) & الخطأ المعياري & B & المعياري & & \\
\hline 0.001 & 5.95 & 4.45 & 26.50 & \multirow{2}{*}{0.27} & الثابت & \multirow{2}{*}{1} \\
\hline 0.01 & 2.62 & 0.08 & 0.21 & & التفكير العملي & \\
\hline
\end{tabular}

جدول (19): معاملات الانحدار المعيارية للتفكير العملي للتنبؤ ببعد الجدة

\begin{tabular}{|c|c|c|c|c|c|c|}
\hline \multirow{2}{*}{ مستوى الدلالة } & \multirow{2}{*}{ قيمة } & \multicolumn{2}{|c|}{ معامل الانحدار غير المعياري } & \multirow{2}{*}{ معامل الانحدار } & \multirow{2}{*}{ 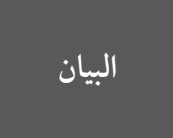 } & \multirow{2}{*}{ النموذج } \\
\hline & & الخططأ المعياري & B & & & \\
\hline 0.001 & 5.85 & 4.55 & 26.60 & \multirow{2}{*}{0.25} & الثابت & \multirow{2}{*}{1} \\
\hline 0.05 & 2.37 & 0.08 & 0.19 & & التفكير العملي & \\
\hline
\end{tabular}

جدول (20): معاملات الانحدار المعيارية للتفكير العملي للتنبؤ ببعد الفعالية

\begin{tabular}{|c|c|c|c|c|c|c|}
\hline مستوى & قيمة & \multicolumn{2}{|c|}{ معامل الانحدار غير المعياري } & \multirow{2}{*}{ معامل الانحدار } & \multirow{2}{*}{ 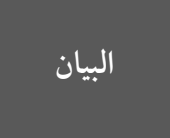 } & \multirow{2}{*}{ النموذج } \\
\hline 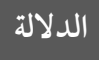 & (ت) & الخططأ المعياري & B & & & \\
\hline 0.001 & 6.23 & 4.18 & 26.04 & \multirow{2}{*}{0.32} & الثابت & \multirow{2}{*}{1} \\
\hline 0.01 & 3.16 & 0.07 & 0.24 & & التفكير العملي & \\
\hline
\end{tabular}

جدول (21): معاملات الانحدار المعيارية للتفكير العملي للتنبؤ بالإبداع الانفعلي 


\begin{tabular}{|c|c|c|c|c|c|c|}
\hline مستوى & قيمة & \multicolumn{2}{|c|}{ معامل الانحدار غير المعياري } & \multirow{2}{*}{ معامل الانحدار } & \multirow{2}{*}{ 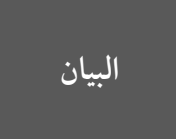 } & \multirow{2}{*}{ النموذج } \\
\hline الدلالة & (ت) & الخطأ المعياري & B & & & \\
\hline 0.001 & 8.92 & 12.41 & 110.71 & \multirow{2}{*}{0.36} & الثابت & \multirow{2}{*}{1} \\
\hline 0.001 & 3.66 & 0.22 & 0.81 & & التفكير العملي & \\
\hline
\end{tabular}

1) إمكانية التنبؤ ببعد الاسـتعداد أو التهيؤ الانفعالي لدى' طلاب الجامعة من خلال

التفكير العملي بمعامل تنبؤ 0.307 بالإضافة إلى ثابت مقداره 31.65.

2) إمكانية التنبؤ ببعد المرونة لدئ طلاب الجامعة من خلال التفكير العملي بمعامـل تنبؤ

$$
0.27 \text { بالإضافة إلى ثابت مقداره } 26.50 .
$$

إمكانية التببؤ ببعد الجحة لدىن طلاب الجلمعة من خلال التفكير العملي بمعامل تنبؤ

$$
0.25 \text { بالإضافة إلى ثابت مقداره } 26.60 .
$$

4) إمكانية التنبؤ ببعد الفعالية لدئ طلاب الجحامعة من خلال التفكير العملي بمعامل

$$
\text { تنبؤ } 0.32 \text { بالإضافة إلى ثابت مقداره } 26.04 .
$$

إمكاذية التنبؤ بالإبداع الانفعلي لدى طلاب الجامعة من خلال التفكير العملي

بمعامل تنبؤ 0.36 بالإضافة إلى ثابت مقداره 110.71 بـ وبناء عليه تم قبول الفرض

$$
\text { الثامن. }
$$

وتفسر الباحثة تلك النتيجة بأن من سمات ذوي التفكير العملي القـدرة على التحقق مما هو صسحيح أو خاطئ بالنسبة للخبرة الشـحسية المباشرة وحرية التجريب والتفوق في إيجاد طر ائق جديدة لعمل الأشــياء بالاسـتعانة بالمو اد الخامة المتاحة كما يمتاز ســلوكهم بالمرونة والقدرة على التكيف وكل هذه السمات من سهات الأفراد المبدعين انفعالياً وهذا يؤكد إمكانية التنبؤ بالإبداع الانفعالي من خلال أسلوب التفكير العملي. 
في ضوء نتائج الدرا سات السابقة وما تو صل إليه هذا البحث من نتائج يمكن تقديم التطبيقات التربوية التالية:

1- توجيه عناية أعضــاء هيئة التدريس بالجامعة إلى ضرورة الاهتحام بأســاليب تفكير الطلبة ووضع برامج علمية هادفة لتطويرها لدى الطلبة. 2- إقامة دورات تدريبية لأعضاء هيئة التدريس تتضمن تطبيق مقاييس وأدوات للتعرف على مستوى أساليب التفكير لدئ الطلبة.

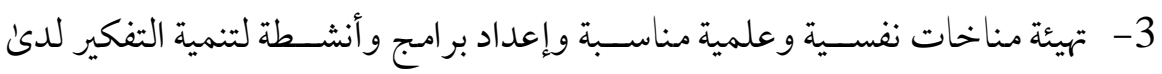
الطلبة. 4- التركيز علن أسلوب التفكير التحليلي والو اقعي أثناء التدريس وليس فقط التركيز على إلقاء المحاضرات، لأن الطلبة في الجامعة ينطوون في غالبيتهم تحت هذا الأسـلوب في التفكير. 5- عقد دورات تدريبية لأعضــاء هيئة التدريس لتعريفهم بأسـاليب التفكير، وكيفية تنميتها لدى طلبة الجامعة. 6- إعداد بر امسج لتنمية القدرات الإبداعية بصـفة عامة لدى طلاب الجامعة، فالعصرالذي نعيش فيه وما يتضمنه من تغيرات وتطورات سريعة يتطلب من الفرد أن يكون مبتكراً في تعامله مع المسئوليات الملقاة على عاتقه. 7- تفعيـــــل دور الجـامعة في الاهتمام بالطلاب والعمل علن تنمية قدراتهم العقلية و الو جدانية، وتهيئة المناخ المناسـبـ لإتاحة الفرص أمامهم للتعبير عن أفكارهم

$$
\text { وتحقيق إنجازات مبتكرة. }
$$


8- إعداد برامج لتنمية الإبداع الانفعالي لدىئ أعضساء هيئة التدريس بالجامعة؛ مما يسهم في خلق مناخ مناسب وفعال في تعاملهم مع الطلاب.

9- اهتحام الأسرة بتنمية قدرات أبنائها على التعبير عن انفعالاتهم، وضــبط انفعالاتهم و إدارتها، وكذلك تنمية القدرات الإبداعية لدى أبنائها وحسن استغلال قدراتهم. 10- إجر اء دراسة مماثلة للدر اسة الحالية علن مراحل التعليم المختلفة. 11-دراسة مدى تأثير أسلوب التفكير علن أسلوب التعلم.

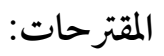

$$
\text { وتقترح الباحثة إجراء البحوث و الدراسات الآتية: }
$$

1- أساليب التفكير وعلاقتها بمهارة اتحاذ القرار لدئ أعضاء هيئة التدريس بالجامعة. 2- أساليب التفكير وعلاقتها بالذكاء الاجتماعي لدى طلبة الجامعة. 3- أساليب التفكير ودلالتها التنبؤية بالإبداع الانفعالي لدىن طلاب المرحلة الإعدادية. 4- أساليب التفكير وعلاقتها بالذكاءات المتعددة لدى طلاب المرحلة الثانوية. 5- فعالية التدريب علن الإبداع الانفعالي في تحسـين المهارات الاجتماعية ومهارات حل

$$
\text { المشكلات لدى طلاب الجامعة. }
$$

6- النموذج البنائي للعلاقة بين الإبداع الانفعالي ومهارات التواصـل وحل المشـكلات لدئ طلاب الجحامعة.

7- الإبداع الانفعالي وعلاقته بالتفكير الناقد و التفكير الابتكاري لدى طلاب الجامعة 
1. إبراهيم إبراهيم أحمد أحمد (2008). أثر تفاعل الابتكار الانفعلي والذكاء الانفعلي

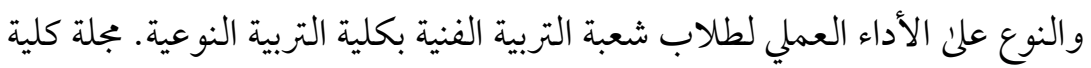

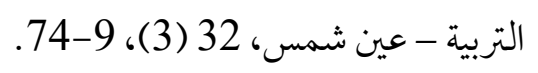

2. أممد محمد مرزوك (2016) . أساليب التفكير وعلاقتها بالاتجاهات التعصبية عند طلبة

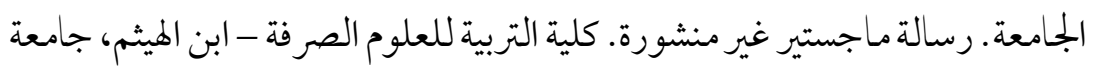

$$
\text { بغداد. }
$$

3. أممد محمد نوري محمود (2014). أساليب التفكير لدئ الطلبة المتميزين. بجلة جرش

$$
\text { للبحوث والدراسات - الأردن، } 15 \text { (2)، 461-479. }
$$

4. بشرئ خطاب عمر وربيعة مانع زيدان (2014). الإبداع الانفعالي وعلاقته ببعض المتغيرات لدن طلبة الجامعة. بجلة الدراسات التاريخية الحضارية، 3 (18)، 380-

.403

5. حاسن بن رافع الشهري (2006). أساليب التفكير لدئ طلاب وطالبات المستويات الأولية والنهائية بجامعة طيبة بالمدينة المنورة. بجلة جامعة الملك سعود - العلوم التربوية والدراسات الإسلامية بالسعودية، 19 (2)، 833-888.

6. حسني زكريا السيد النجار (2010). بروفيلات أساليب التفكير المفضلة لدئ التلاميذ بهدئ الموهوبين وذوي صعوبات التعلم والعاديين وعلاقتها بالتوافق الدراسي والتحصيل رئل الأكاديمي. مجلة كلية التربية بالإسكندرية، 20 (3)، 160-284.

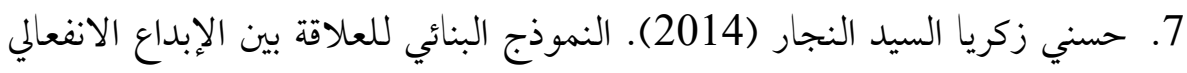
وقعالية الذات الانفعالية ومهارات اتخاذ القرار لدئ طلاب الجامعة. بجلة كلية التربية - - جامعة بنها، 25 (98)، 101-144. 
8. حليم صخيل العنكوشي (2018). الانفعال الإبداعي ومرونة الأنا لدى الإمام زين العابدين عليه السلام بعد فاجعة كربلاء: دراسة تحليلية. مجلة الكلية الإسلامية

$$
\text { الجامعة، } 46 \text { (2)، 499-531. }
$$

9. ر رائدة عطية أبو عبيد (2017). أساليب التفكير وعلاقتها بمعوقات اتخاذ القرار لدى طلبة قسم الإرشاد النفسي في جامعة الأقصن. مجلة جامعة الأزهر - غزة، سلسلة

$$
\text { العلوم الإنسانية، } 19 \text { (1)، 147-176. }
$$

10. ربيعة مانع زيدان الحمداني (2014). الإبداع الانفعالي وعلاقته بالقيادة التربوية لدىن مدراء المدارس الثانوية. مجلة جرش للبحوث و الدراسات - الأردن، 15 (2)، 17-

11. ردمان محمد سعيد غالب (2001) . أساليب التفكير لدى' معلمي الثانوية قبل الخدمة.

$$
\text { مجلة الدراسات الاجتماعية، 11، 7-32-3 }
$$

12. رشار رجب السيد إبر اهيم عيد (2015). الابتكار الانفعالي وعلاقته بالعو امـل الخمسة الكبرى للشخصية لدى' عينة من طلاب الجامعة. مجلة دراسات عربية في علم النفس

$$
\text { - مصر، } 14 \text { (4)، 665- }
$$

13. ريهام زغلول عبد السميع بركات (2016). الإبداع الانفعالي وعلاقته بأساليب المواجهة لدئ عينة من طلاب الجامعة. بجلة كلية التربية، جامعة بنها، 1-16. 14. زينب عبد العليم بدوي (2011). النموذج البنائي للعلاقات بين الإبداع الانفعالي وبعض متغيرات تجهيز المعلومات الانفعالية. دراسات تربوية ونفسية، بجلة كلية

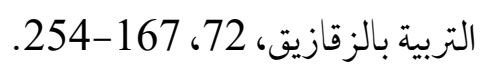


15. سامح أمد سعادة (2012). تمييز الابتكار الانفعلي عن الابتكار المعرفي والذكاء الانفعالي لدن الشباب من الجنسين. مجلة كلية التربية، جامعة طنطا، 46، 129-

16. سمية بن عائشة (2015). أساليب التفكير وعلاقتها بالتكيف المدرسي لدئ التلاميذ المتفوقين دراسياً والعاديين في المرحلة الثانوية. رسالة ماجستير غير منشورة. كلية العلوم الإنسانية والاجتماعية، جامعة الحاج لخضر - باتنة.

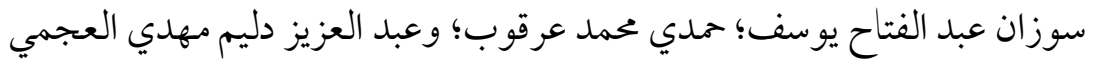

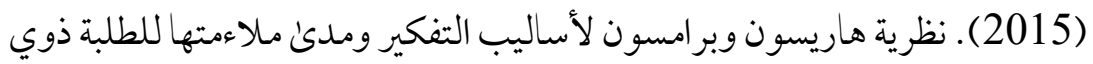

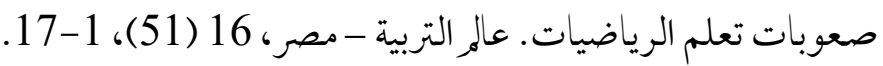
18. صلاح عبد السميع مهدي باشا (2005). الفروق بين المعلمين في أساليب التفكير بالمنطقة الشرقية بالمملكة العربية السعودية. مجلة بحوث التربية النوعية - مصر، 6، $.145-100$ 19. صبحية أمد عبد القادر محمد (2019). أساليب التفكير في ضوء نظرية ستيرنبرج

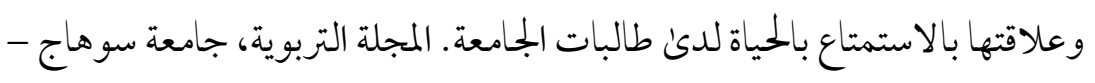

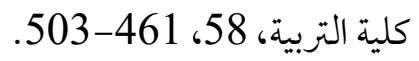
20. صفاء علي أحمد عفيفي (2016). الاسهام النسبي للإبداع الانفعلي واستراتيجيات الدراسة في أبعاد الإندماج الأكاديمي في ضوء النوع و التخصص لدئ طلاب الجامعة. بجلة كلية التربية في العلوم النفسية، كلية التربية، جامعة عين شمس، 40 (3)، 62.202 
21. طارق توفيق المصري وعلي فرح أحد فرح (2019). دافعية الإنجاز وعلاقتها بأساليب التفكير لدى طلبة جامعة الملك فيصل بالمملكة العربية السعودية. دراسات عربية في التربية وعلم النفس، رابطة التربويين العرب، 108، 214-246. 22. طلال عبد الله الزعبي ومحمد الشريدة (2007). أساليب التفكير الشائعة لدىن طلبة جامعة الحسين بن طلال وتأثرها بكل من الجنس والتخصص والمستوى الدراسي. بجلة اتحاد الجحامعات العربية للتربية وعلم النفس، 5 (2)، 1-26. 23. عادل سعد يوسف خضر (2009). الإبداع الانفعالي وعلاقته بكل من قوة السيطرة المعرفية والقيم لدىن عينة من طلاب الصف الثالث الإعدادي. مجلة التربية، قطر، 38 .140-94،(170) 24. عبد الرحمن قشاشطه (2016) مصدر الضبط الداخلي/ الخارجي وعلاقته بأساليب التفكير لدى أساتذة التعليم الثانوي: دراسة ميدانية بثانويات دائرة حاسي خليفة ولاية الوادي. رسالة ماجستير. غير منشورة. كلية العلوم الإنسانية الاجتماعية،

$$
\text { جامعة لونيسي علي - البليدة2 }
$$

25. عبد الله عبد الهادي العنزي (2016). أساليب التفكير ومستوئ الطموح الأكاديمي ودور هما في التنبؤ بالتسويف الأكاديمي لدئ طلاب الجامعة. المجلة الدولية التربوية

$$
\text { المتخصصة، } 5 \text { (8)، 96-134. }
$$

26. عبود جواد راضي (2016). أساليب التفكير في ضوء نظرية هاريسون وبرامسون وعلاقتها ببعض المتغيرات لدئ طالبات مرحلة الدراسة الإعدادية. مجلة كلية التربية،

$$
\text { جامعة واسط، } 1 \text { (22)، 533-564. }
$$


27. علا عبد الرحمن علي محمد (2014). أساليب التفكير وعلاقتها بتقدير الذات

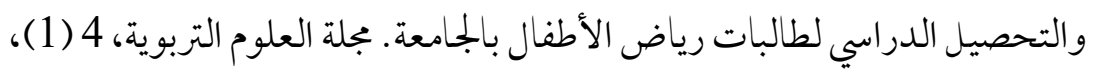

$$
30-1
$$

28. علي محمد الشلوي (2010) . أساليب التعلم وأساليب التفكير وعلاقتها بالتحصيل الدراسي لدىن عينة من طلاب جامعة الطائف في ضوء تخصص الطالب ومستواه الدراسي. رسالة دكتوراه غير منشورة. كلية التربية، جامعة اليرموك.

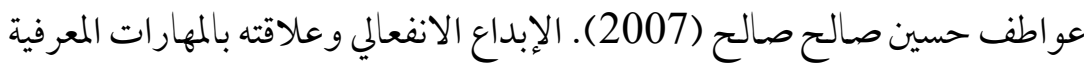
والحاجة للتقييم لدن الشباب الجامعي. مجلة كلية التربية بالزقازيق، 56، 143-

30. غادة طه عبد الحفيظ محمد وعلية عثمان سيد (2017). دراسة أساليب التفكير في

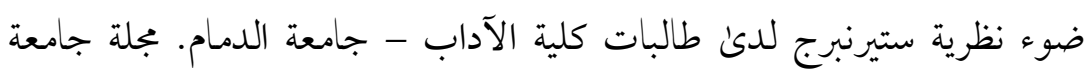

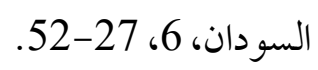

31. فتحي جو اد القلاف (2012) . الإبداع الوجداني لدئ طلاب وطالبات الثانوية العامة

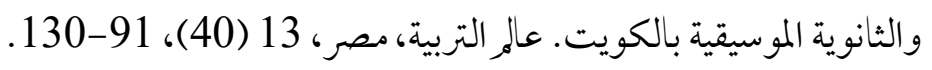
32. فيصل خليل الربيع؛ عمر شواشرة؛ وتغريد عبد الرحمن محمد حجازي (2014).

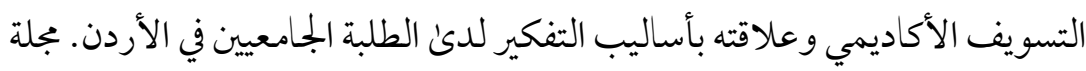

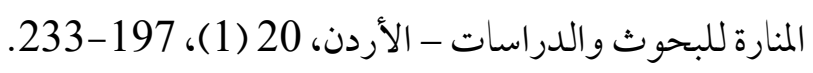

33. كريان عويضة منشار (2002). الابتكارية الانفعالية وعلاقتها بكل من التفكير

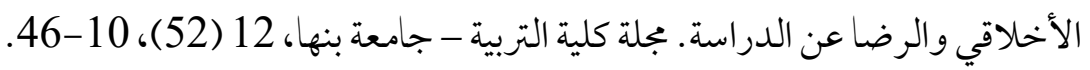


34. محمد السيد علي عبد المعطي (2007). أساليب التفكير لدى المعلمين والمعلمات بمدارس التعليم الثانوي العام وعلاقتها ببعض المتغيرات. مجلة دراسات تربوية

$$
\text { واجتماعية بمصر، } 13 \text { (2)، 53-104. }
$$

35. حمد بن حسن أبو راسين (2015) ـ أنماط التعلق في علاقتها بكل من الذكاء الو جداني والإبداع الوجداني لدئ عينة من طلبة المرحلة الثانوية. مجلة الإرشاد النفسي، 41،

36. محد رزق البحيري (2012). النموذج البنائي لعلاقة الإبداع الوجداني ببعض المتغيرات لدئ الأطفال ذوي صعوبات التعلم الاجتماعي. مجلة دراسات عربية في

$$
\text { علم النفس - مصر، } 11 \text { (3)، 365-417. }
$$

37. محمد كادي (2016). علاقة أساليب التفكير بالدافعية للإنجاز لدئ طلاب المرحلة الثانوية. رسالة ماجستير غير منشورة. كلية العلوم الإنسانية والاجتماعية، جامعة أبي بكر بلقايد.

38. مصلح مسلم مصطفى المجالي (2019). أساليب التفكير السائدة لدى المتفوقين دراسياً من طلبة الجامعة وعلاقتها ببعض المتغيرات: دراسة نفسية - إرشادية تحليلية. بجلة العلوم الاجتتاعية، جامعة الكويت - بجلس النشر العلمي، 47 (1)، $.104-71$

39. مظهر محمد عطيات (2013). أنحاط التفكير في ضوء نظرية ستيرنبرغ لدى' طلبة جامعة البلقاء التطبيقية وعلاقتها ببعض المتغيرات. مجلة دراسات، العلوم التربوية، 
40. نافز أحمد عبد بقيعي (2012) . أساليب التفكير و العو امل الخمسة الكبرى للشخصية

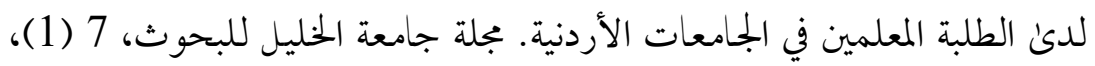
.131-107

41. نهلة عبد الهادي مسير العابدي (2017). الإبداع الانفعالي وعلاقته بالتوجه نحو الحياة لدئ طلبة الجامعة. رسالة ماجستير غير منشورة. كلية التربية، جامعة القادسية. 


\section{References:}

- Abdel Baqi, N. A. (2012). Thinking styles and the five major factors of personality among Jordanian teachers. Hebron University Journal of Research, 7 (1), 107-131.

- Abdel Moati, M. E. A. (2007). Styles of thinking among teachers and teachers in general secondary education schools and their relation to some variables. Journal of Educational and Social Studies in Egypt, 13 (2), 53-104.

- Abu Obaid, R. A. (2017). Styles of thinking and its relation to the obstacles of decision-making among students of psychological counseling department at Al-Aqsa University. Al-Azhar University Journal - Gaza, Human Sciences Series, 19 (1), 147176.

- Abu Rasin, M. B. (2015). Attaching patterns in relation to both emotional intelligence and emotional creativity in a sample of secondary students. Journal of Psychological Counseling, 41, 133-222.

- Afifi, S. A. A. (2016). The relative contribution of emotional creativity and study strategies in the dimensions of academic integration in the light of gender and specialization among university students. Faculty of Education, Ain Shams University, 40 (3), 62-202.

- Ahmed, I. I. A. (2008). Effect of interaction of emotional innovation, emotional intelligence and gender on the practical performance of the students of the Department of Art 
Education, Faculty of Specific Education. Journal of Faculty of Education - Ain Shams, 32 (3), 9-74.

- $\quad$ Al - Abidi, N. A. M. (2017). Emotional creativity and its relation to the orientation towards life among university students. Unpublished Master Thesis. Faculty of Education, University of Qadisiyah.

- Al-Anzi, A. A. (2016). Styles of Thinking and the level of academic ambition and their role in predicting the academic delay of university students. Journal of Specialized Education, 5 (8), 96134.

- $\quad$ Al-Hamdani, R. M. Z. (2014). Emotional creativity and its relation to the educational leadership of high school principals. Jerash Journal for Research and Studies - Jordan, 15 (2), 17-35.

- Al Masri T. T. \& Farah. A. F. A. (2019). The motivation of achievement and its relation to thinking styles at King Faisal University in Saudi Arabia. Arab Studies in Education and Psychology, Arab Education Association, 108, 214-246.

- $\quad$ Al-Qallaf, F. G. (2012). Emotional creativity of Kuwaiti secondary and high school students. The World of Education, Egypt, 13 (40), 91-130.

- Al-Rabee, F. K.; Shawashrah, O. \& Hijazi, T. A. M. (2014). Academic procrastination and its relation to the thinking styles of university students in Jordan. Al Manara Journal for Research and Studies - Jordan, 20 (1), 197-233. 
- $\quad \mathrm{Al}$ - Shihri, H. R. (2006). Styles of thinking among students of primary and final levels at the University of Taiba in Medina. King Saud University - Educational Sciences and Islamic Studies in Saudi Arabia, 19 (2), 833-888.

- Al-Zu'bi, T. A. \& Al-Sharida, M. (2007). The common thinking styles of the students of Al-Hussein Bin Talal University and their impact easily from sex, specialization and level of education. Journal of the Union of Arab Universities for Education and Psychology, 5 (2), 1-26.

- $\quad$ Ankhushi, H. S. (2018). Creative emotion and flexibility of the ego of Imam Zine El Abidine peace after the tragedy of Karbala: an analytical study. Journal of Islamic University College, 46 (2), 499-531.

- Attiyat, M. M. (2013). Patterns of thinking in the light of the Sternberg theory in the students of Balqa Applied University and its relation to some variables. Journal of Studies, Educational Sciences, 40 (3), 1135-1159.

- Cady, M. (2016). Relationship of thinking styles of motivation to achievement among high school students. Unpublished Master Thesis. Faculty of Humanities and Social Sciences, University of Abu Bakr Belqayd.

- $\quad$ El-Beheiry, M. R. (2012). The structural model of the relationship of emotional creativity to some variables in children with social learning disabilities. Journal of Arab Studies in Psychology Egypt, 11 (3), 365-417. 
- El Naggar, H. Z. E. (2010). Profiles of preferred thinking styles of gifted students with learning disabilities and their relation to academic compatibility and academic achievement. Journal of the Faculty of Education, Alexandria, 20 (3), 160-284.

- El-Naggar, H. Z. E. (2014). The constructive model of the relationship between emotional creativity, emotional selfefficacy, and decision-making skills of university students. Journal of the Faculty of Education - Banha University, 25 (98), 101-144.

- Badawi, Z. A. (2011). The The structural model of the relationship between emotional creativity and some variables of emotional processing information. Educational and Psychological Studies, Zagazig College of Education Journal, 72, 167-254.

- $\quad$ Barakat, R. Z. A. (2016). Emotional creativity and its relation to the methods of confrontation among a sample of university students. Journal of the Faculty of Education, Benha University, 1-16.

- Bin Aisha, S. (2015). Styles of thinking and their relation to school adaptations among students who highly educated and ordinary in secondary school. Unpublished Master Thesis. Faculty of Humanities and Social Sciences, University of Haj Lakhdar Batna.

- Eid, R. R. E. I. (2015). Emotional innovation and its relation to the five major personality factors in a sample of university students. Journal of Arab Studies in Psychology - Egypt, 14 (4), 665-702. 
- Fan,J. (2016). The role of thinking styles in career decision-making selfefficacy among university students, Thinking Skills and Creativity, 20, 63-73.

- Ghaleb, R. M. S. (2001). Styles of thinking of secondary teachers before service. Journal of Social Studies, 11, 7-32.

- $\quad$ Khader, A. S. Y. (2009). Emotional creativity and its relation to both the power of cognitive control and values in a sample of students in the third grade preparatory. Journal of Education, Qatar, 38 (170), 94-140.

- Mahmoud, A. M. N. (2014). Styles of thinking of Distinguished students. Jerash Journal for Research and Studies - Jordan, 15 (2), 461-479.

- Majali, M. M. M. (2019). Styles of thinking prevalent among the outstanding students from the university students and their relation to some variables: A psychological study - guidance analytical. Journal of Social Sciences, Kuwait University Scientific Publishing Council, 47 (1), 71-104.

- Marzouk, A. M. (2016). Styles of Thinking and their relationship to the trends of fanaticism among university students. Unpublished Master Thesis. Faculty of Education for Pure Sciences - Ibn al-Haytham, University of Baghdad.

- Menshar, K. A. (2002). Emotional innovation and its relation to both moral thinking and satisfaction with the study. Journal of the Faculty of Education - Banha University, 12 (52), 10-46. 
- $\quad$ Mohamed, G. H. A. \& Sayed, A. O. (2017). Study of thinking styles in the light of the Sternberg theory of students of the Faculty of Arts - University of Dammam. University of Sudan Journal, 6, 27-52.

- $\quad$ Mohamed, O. A. A. (2014). Styles of Thinking and its Relation to Self-Esteem and academic achievement of female kindergarten students at the university. Journal of Educational Sciences, 4 (1), 1-30

- Mohammed, S. A. A. (2019). Styles of Thinking $n$ the light of Sternberg's theory and its relation to the enjoyment of life among university students. Educational Journal, Sohag University - Faculty of Education, 58, 461-503.

- Navan, S. F., Shariatmadarithe, M. (2015). Relationship between functions of thinking styles and academic achievement motivation among students of payame Noor university, Iran, Indian. Journal of Fundamental and Applied Life Sciences 5 (S3), 1699-1708.

- Nezhdyan, F. G. \& Adbi, B. (2010). Factor structure of emotional creativity inventory (ECI-Averill, 1999) among Iranian undergraduate students in Tehran universities. Procedia Social and Behavioral Sciences, 5, 1836-1840.

- $\quad$ Omar, B. K. \& Zidan, R. M. (2014). Emotional creativity and its relation to the use of variables among university students. Journal of Historical and Cultural Studies, 3 (18), 380-403.

- Qashashtah, A. R. (2016). The source of internal / external control and its relation to the thinking methods of the teachers of 
secondary education: a field study in the priorities of the Department of Hassi Khalifa Valley State. Unpublished Master Thesis.. Faculty of Social Humanities, University of Lounisi Ali - Blida 2.

- $\quad$ Pasha, S. A. M. (2005). Differences between teachers in thinking styles in the Eastern Province of Saudi Arabia. Journal of Specific Education Research - Egypt, 6, 100-145.

- $\quad$ Radi, A. J. (2016). Styles of Thinking in the light of the theory of Harrison and Bramson and its relationship to some variables in the students of the preparatory stage. Journal of the Faculty of Education, Wasit University, 1 (22), 533-564.

- $\quad$ Saadeh, S. A. (2012). Emotional innovation is distinguished from cognitive innovation and emotional intelligence among young people of both sexes. Journal of the Faculty of Education, Tanta University, 46, 129-185.

- $\quad$ Saleh, A. H. S. (2007). Emotional creativity and its relationship to cognitive skills and the need for evaluation among university youth. Journal of the Faculty of Education Zagazig, 56, 143199.

- Shalawi, A. M. (2010). Styles of learning \& thinking and their relation to the academic achievement of a sample of students of the University of Taif in light of the student's specialization and academic level. Unpublished Doctoral Dissertation. Faculty of Education, Yarmouk University. 
- Shama, D. \& Mathyr, R. (2016). Linking hope and emotional creativity: meditational role of positive affect. The International Journal of Indian Psychology, 3 (4) (58), 50-61.

- $\quad$ Soroa, G. Gorostiaga, A. Arizeta, A. \& Balluerka, N. (2015). A shortened Spanish version of the emotional creativity inventory (the ECI-S). Creativity Research Journal, 27 (2), 232-239.

- Turki, J. (2012). Thinking styles in light of Sternberg's theory prevailing among the students of Tafila Technical University and its relationship with some variables. American International Journal of Contemporary Research, 2(3), 140-152.

- Wang, H.,Chang, W. Land Lai,Y. (2012). A study on the relationship between thinking styles (Attitudes) and collaboration attitudes of colleage students in Tiaiwan. Journal of Educational and Instructional Studies in the World, 2 (7), 46-57.

- Wang, G. Huang, H. \& Zheng, Q. (2015). Effect oc Chinese employees emotional creativity on their innovative performance. Social Behavior and Personality, 43 (7), 1147-1160.

- $\quad$ Youssef, S. A. ; Arkoub, H. M. \& Ajmi, A. D. M. (2015). Harrison and Bramson Theory of thinking styles and their suitability for students with learning disabilities in mathematics. The World of Education - Egypt, 16 (51), 1-17.

- Zareie, H. (2014). Structural modeling of the relationship between emotional creativity, self-efficacy and academic motivation among students. Bulletin of Environment, Pharmacology and Life Sciences, 3, 27-30. 
